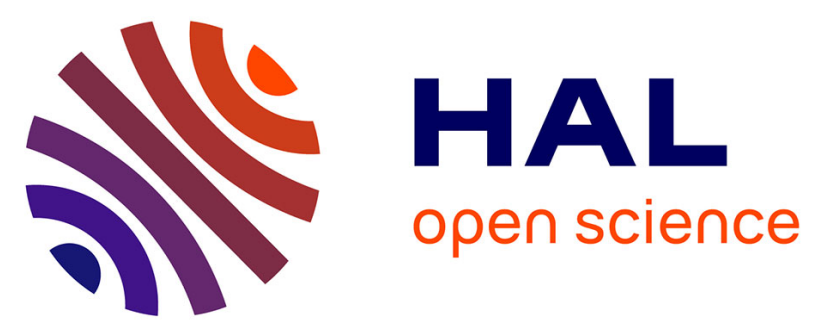

\title{
Exhumation of an anatectic complex by channel flow and extrusion tectonics: structural and metamorphic evidence from the Porto -Viseu Metamorphic Belt, Central-Iberian Zone
}

T. Bento dos Santos, J. F Rodrigues, P. Castro, B. Cotrim, Inês Pereira, J. A Ferreira, C. Meireles, N. Ferreira, P. Ferreira, A. Ribeiro, et al.

\section{To cite this version:}

T. Bento dos Santos, J. F Rodrigues, P. Castro, B. Cotrim, Inês Pereira, et al.. Exhumation of an anatectic complex by channel flow and extrusion tectonics: structural and metamorphic evidence from the Porto -Viseu Metamorphic Belt, Central-Iberian Zone. International Journal of Earth Sciences, 2021, 110 (6), pp.2179-2201. 10.1007/s00531-021-02067-z . hal-03349192

\author{
HAL Id: hal-03349192 \\ https://hal.uca.fr/hal-03349192
}

Submitted on 20 Sep 2021

HAL is a multi-disciplinary open access archive for the deposit and dissemination of scientific research documents, whether they are published or not. The documents may come from teaching and research institutions in France or abroad, or from public or private research centers.
L'archive ouverte pluridisciplinaire HAL, est destinée au dépôt et à la diffusion de documents scientifiques de niveau recherche, publiés ou non, émanant des établissements d'enseignement et de recherche français ou étrangers, des laboratoires publics ou privés. 


\title{
Exhumation of an anatectic complex by channel flow and
}

\section{extrusion tectonics: structural and metamorphic evidence from}

\section{the Porto - Viseu Metamorphic Belt, Central-Iberian Zone}

5 T. Bento dos Santos ${ }^{1,2^{*}}$, J.F. Rodrigues ${ }^{3,4}$, P. Castro ${ }^{3}$, B. Cotrim ${ }^{1}$, I. Pereira ${ }^{5}$, J.A. Ferreira ${ }^{1}$, C. Meireles ${ }^{3}$, N. Ferreira ${ }^{3}$, P. Ferreira ${ }^{6}$, A. Ribeiro ${ }^{1,2}$, F. Guimarães ${ }^{3}$

${ }^{1}$ Instituto Dom Luiz (IDL), Faculdade de Ciências, Universidade de Lisboa, Campo Grande, 1749-016, Lisboa, Portugal

${ }^{2}$ DG-FCUL - Departamento de Geologia, Faculdade de Ciências, Universidade de Lisboa, Campo Grande, 1749016, Lisboa, Portugal

${ }^{3}$ LNEG - Laboratório Nacional de Energia e Geologia, 2720-866 Amadora, Portugal

${ }^{4}$ FEUP - Faculdade de Engenharia da Universidade do Porto, 4200-465 Porto, Portugal

${ }^{5}$ Université Clermont Auvergne, CNRS, IRD, OPGC, Laboratoire Magmas et Volcans, F-63000 ClermontFerrand, France

${ }^{6}$ ICT - Instituto de Ciências da Terra, 4169-007 Porto, Portugal

(*Corresponding author: tmsantos@fc.ul.pt)

Abbreviated title: Anatectic complex exhumation by channel flow

\begin{abstract}
Structural and metamorphic analyses of the Porto - Viseu Metamorphic Belt (PVMB), an anatectic complex located in the Central-Iberian Zone (CIZ), Iberian Variscan Massif, constrain the kinematic features of the polyphase Variscan deformation, as well as the boundary conditions associated to the exhumation and emplacement of the belt onto the CIZ's lower-grade metasediments.
\end{abstract}

A sharp metamorphic contrast is evident between the lowest grade rocks of the anatectic complex - garnetstaurolite mylonitic schists with minimum metamorphic peak at $\mathrm{P}=5.7 \mathrm{kbar}$ and $\mathrm{T}=635^{\circ} \mathrm{C}-$ and the host chloritebiotite metasediments of the CIZ. Additional P-T estimates for metatexites in the PVMB provided P $=7.6-7.9$ kbar and $\mathrm{T}=770-810^{\circ} \mathrm{C}$, confirming high-grade metamorphic peak conditions. The temperature jump between 
the anatectic complex and the low grade host rocks exceeds $400{ }^{\circ} \mathrm{C}$ if the anatectic core of the belt (metatexites, diatexites and S-type granites) is considered, implying a vertical difference of 10-17 km.

The PVMB is limited in the NE by a D2 shear zone displaying normal kinematics, which has been explained so far by extensional tectonics. However, the SW boundary is limited by a D2 shear zone showing reverse kinematics. This pair of coeval and antithetical ductile shear zones bordering the PVMB, associated with the increase of the metamorphic grade towards the axial domain of the belt, is consistent with anatectic channel flow, followed by extrusion tectonics of the PVMB within an overall D2 compressive setting.

Keywords: Variscan Orogeny; anatectic complex; antithetical kinematics; channel flow; P-T modelling

\section{INTRODUCTION}

Anatectic complexes are the result of partial melting of the middle and lower crust under conditions of highgrade metamorphism and are usually associated in space to syn-orogenic granitic bodies (Wimmenauer \& Brihni 2007; Bento dos Santos et al. 2011a; Pereira et al. 2017b). For this reason, many anatectic complexes present the highest temperature record of an orogenic belt, which makes their study crucial to understanding the overall metamorphic evolution of an orogenic belt (e.g.: Sawyer et al. 2011; Bento dos Santos et al. 2011b; Pereira et al. 2017a), the scale and timing of the processes of deformation, metamorphism, magmatism and exhumation (e.g.: Vielzeuf \& Holloway 1988; Whitney et al. 2004; Bento dos Santos et al. 2010) and, in a larger and global perspective, the processes of compositional differentiation and secular evolution of the crust (e.g.: Fyfe 1973; Aranovich et al. 2014).

The Central-Iberian Zone (CIZ), located in the NW of the Iberian Peninsula (Fig. 1a), is part of the European Variscan Belt (Diez Balda et al. 1995; Ribeiro et al. 1990; 2009; Schulmann et al. 2002; Dias \& Ribeiro 2013; Ntarmouchant et al. 2016) and is essentially composed of Neoproterozoic Cambrian low-grade (chlorite-biotite zone) metasediments intruded by syn- to post-tectonic Variscan granitoids (Sousa \& Sequeira 1993; Talavera et al. 2012; Azevedo \& Valle Aguado 2013; Ferreira et al. 2020). In the CIZ, migmatites are scarce and always located within anatectic complexes in the vicinities of first-order shear zones that delimit these anatectic complexes and place them in contact to the regional low-grade metasedimentary sequence (e.g.: Pereira et al. 2017a; Ferreira et al. in press). In the western sector of the CIZ, some anatectic complexes have been described: the Porto-Viseu Metamorphic Belt 
(PVMB; Reavy et al. 1991; Valle Aguado et al. 2005; Silva 2014); the Figueira de Castelo Rodrigo -

Lumbrales Anatectic Complex (FCR-LAC; Iglesias \& Ribeiro 1981; Escuder Viruete et al. 1994; Fernández \& Pereira 2016; Pereira et al. 2017a; Ferreira et al. 2019; 2020); the Miranda do Douro Anatectic Complex (MDAC; Castro et al. 2003; Gomes et al. 2011; 2013); and the Serra da Estrela Anatectic Complex (SEAC; Ferreira \& Silva 1999; Amaro et al. 2016).

The Porto - Viseu Metamorphic Belt (PVMB; Fig. 1), located in central-north Portugal and in the NW sector of the CIZ, is a NW-SE elongated variscan high-grade belt (Valle Aguado et al. 2005; Ribeiro et al. 2019 and references therein) and has long been considered a thermal anomaly within the overall pattern of the CIZ (Soen 1958; Reavy et al. 1991; Acciaioli et al. 2005; Valle Aguado et al. 2005; Ribeiro et al. 2014; Cotrim et al. in press), particularly when compared to the metamorphic base reference low-grade slate belt, the Douro - Beiras Supergroup of Neoproterozoic to Lower Cambrian age (Sousa \& Sequeira 1993; Ferreira et al. 2010). Although the geodynamic understanding of the PVMB within the CIZ has had an outstanding growth in the last decades with the contribution of several seminal works (Valle Aguado et al. 1993; 2005; Ribeiro 2013 and references therein), this region has mostly been studied for the deformation mechanisms, kinematics, strain and relationship of individual shear zones to the variscan deformation events, with minor integration of the thermo-tectonic events (Valle Aguado et al. 1993; Valle Aguado \& Azevedo 2006; Bento dos Santos et al. 2010) and their significance regarding the boundary limits of the belt itself. This has hindered the full understanding of the processes of deformation, metamorphism, magmatism and exhumation of this anatectic complex and is the probable reason for some conflicting models (e.g.: Ribeiro et al. 1990; Dias \& Ribeiro 1994; Valle Aguado et al. 2005; Ribeiro et al. 2014).

In this work, structural and metamorphic analyses coupled with geothermobarometric estimates was performed on key sectors of the PVMB where the high-grade anatectic rocks are juxtaposed onto the low-grade metasedimentary sequences of the CIZ, in order to: a) characterize the shear zones delimiting the PVMB; b) correlate thermo-tectonic events and the metamorphic evolution of the belt; and c) understand the exhumation path of the anatectic complex within the deformation events of the CIZ, and, thus, integrating some of the contrasting models into a more complete view of the geodynamic evolution of the PVMB. 


\section{GEOLOGICAL SETTING}

The CIZ, located in the axial domain of the Iberian Variscan Massif (Fig. 1a; Julivert et al. 1972; LNEG 2010), was formed during the Variscan Orogeny by the collision of the supercontinents Gondwana and Laurussia, from which Pangaea resulted (Dias et al. 2013 and references therein). The CIZ autochthonous sequences comprise the Ediacaran - Cambrian, flyschoid Douro - Beiras Supergroup, Ordovician - Lower Devonian siliciclastic sequences and syn-orogenic Carboniferous intramountainous sediments (e.g.: Gutiérrez-Marco et al. 1990; Oliveira et al. 1992; Dias et al. 2013), all of which are affected by low- to very low-grade metamorphism, except when in the vicinity of syn-, late- or postorogenic variscan granitoids. High-grade metamorphic rocks are only found in anatectic complexes bounded by large-scale shear zones, clearly related to their exhumation (Ferreira et al., 2019; in press and references therein).

Regarding the geodynamic evolution of the CIZ, three main deformation phases are described for the collisional process that amalgamated the Iberian terranes and represents the Variscan Orogeny in the NW Iberian Variscan Massif (e.g.: Noronha et al. 1979; Ribeiro et al. 1990; Dias et al. 2013 and references therein). D1 (370 - 350 Ma) is pervasive and penetrative at all scales, forming an axial plane cleavage of the macro-folds that delineate the Iberian - Armorican Arc (IAA) (e.g.: Ribeiro et al. 1990). In the southern branch of the IAA, where the PVMB is located, D1 sinistral shear zones developed in a regime of strain partitioning (Dias \& Ribeiro 1994; Dias et al. 2013). D3 (320 - 300 Ma), homoaxial with D1, is temporally constrained by the emplacement of syn-kinematic variscan granitoids. Important regional D3 shear zones with similar age are also described (see below). While Variscan D1 structures are ubiquitous in the CIZ and D3 are very abundant and associated with the emplacement of most orogenic granites, D2 (350 - 320 Ma) structures are, in most cases, absent with the exception of the Galiza - Trás-os-Montes nappes in NW Iberia (e.g.: Ribeiro 1974; Ribeiro et al. 1990) and in the very high-grade anatectic complexes (Dias et al., 2013 and references therein), such as the PVMB (Valle Aguado et al. 2005). However, this does not necessarily mean that these D2 structures are contemporaneous (Dias et al. 2013).

The PVMB is composed of an anatectic complex that includes high-grade metamorphic rocks 115 (staurolite- and sillimanite-bearing schists and migmatites) and S-type granites (e.g.: Valle Aguado et al. 2005) and shows as general strike a NW-SE direction parallel to the regional orogenic trend, and is 
located in the vicinity of two of the most important shear zones in the Iberian Massif: the Porto-Tomar Shear Zone (PTSZ), and the Douro-Beiras Shear Zone (DBSZ) (Fig. 1b). In the NW and SE extremities of the PVMB, where there is great abundance of syn-D3 (320-310 Ma) and late- to post-D3 (310-290 Ma) variscan granitoids (LNEG 2010; Azevedo \& Valle Aguado 2013), it is more difficult to observe their borders and the relationship with the CIZ's slate belt low-grade metasediments. In the central part of the PVMB, where rocks are well exposed, their boundaries are easier to observe and study. In this central zone it is possible to observe that the PVMB is not intersected by the PTSZ or by the DBSZ, even though, further NW, all these structures can converge (Fig. 1b).

Also, in its SE extremity, the PVMB is deflected by the activity of the Juzbado - Penalva do Castelo Shear Zone (JPCSZ) (Fig. 1b). The late activity of the JPCSZ caused the distortion and folding of the D1 and D2 variscan macrostructures in the SE sector of the PVMB during the D3 intracontinental collision phase (Iglesias \& Ribeiro 1981; Ribeiro et al. 1990; Pereira et al. 2017a). This late deformation stage could have lasted until $296 \mathrm{Ma}$ (Valle Aguado et al. 2017).

\section{METHODOLOGY}

Location of the studied areas and samples is presented in Fig. 1 and 2. Samples were prepared for thin sections and chemical analyses at the laboratories of LNEG in Porto and IDL in Lisbon. Mineral composition data were determined on carbon coated polished thin sections using a JEOL JXA 8500-F Electron Microprobe (EPMA) equipped with 5 wavelength dispersive spectrometers at LNEG in Porto and also in DG-FCUL at the University of Lisbon. Minerals were analysed with an acceleration voltage of $15 \mathrm{kV}$ and a current of $10 \mathrm{nA}$. Both natural and synthetic silicates were used as standards. Errors are typically below $1.5 \%$ for major elements. Structural formulae and activities for all the analysed minerals were obtained with the A-X tool of the THERMOCALC software, v. 3.33 (Holland \& Powell 1998), whereas P-T estimates were obtained using the main THERMOCALC software, v. 3.33 (Holland \& Powell 1998) that uses an internally-consistent thermodynamic database. Errors associated with the PT estimates are in the typical order of $\pm 50^{\circ} \mathrm{C}$ and $\pm 1.0 \mathrm{kbar}$ (e.g.: Hodges \& Crowley 1985). Standard methodological procedures involving the rationale for P-T calculations can be found in Spear \& Florence (1992), Bento dos Santos et al. (2011b; 2014) and Jesus et al. (2016). 


\section{STRUCTURAL ANALYSIS OF THE PORTO - VISEU METAMORPHIC BELT}

The obtained and compiled field structural data (Fig. 2-3) show that there are substantial differences between the variscan strain geometries within the PVMB and outside it, corresponding to different types of ductile flow. In the PVMB, non-coaxial flow with finite stretching and transport perpendicular to the orogenic trend predominates, whereas in the host rocks of the Douro - Beiras Supergroup, pure-shear flow with stretching parallel to the orogenic trend is frequent (Ribeiro et al. 1990; Dias et al. 2013). Transition between these two contrasting material flows is sharp and is also materialized by a significant metamorphic contrast between the PVMB - an anatectic complex - and the adjacent units (chloritebiotite metasediments), both to the NE and SW (e.g.: Oen 1970; Reavy et al. 1991; Valle Aguado \& Martínez Catalán 1993, 1994; Valle Aguado et al. 2005). In order to fully understand the referred structural (geometric and kinematic) contrast, the following aspects were taken into account: a) the deformation history of the PVMB and of the surrounding CIZ slate belt based on foliation transposition and on folding interference patterns; and b) their kinematic interpretation in order to unravel different types of ductile flow.

\subsection{The Variscan polyphasic deformation in the CIZ and in the PVMB}

There is a significant contrast between the deformation sequence in the PVMB - that shows more than two deformation phases (e.g.: Valle Aguado \& Martinez Catalán 1993, 1994) - and in the CIZ slate belt, where D1 and D3 are conspicuous and D2 occurs only in local domains (e.g.: Noronha et al. 1971; Ribeiro et al. 1990; Dias \& Ribeiro 1994; Dias et al., 2013, 2016).

In the low-grade metasedimentary units adjacent to the PVMB, the penetrative planar fabric is a slaty cleavage (S1) which corresponds to the axial plane of regional D1 macrofolds. The transposition of the S1 slaty cleavage may be observed associated to the syn-kinematic granites, where the influence of D3 is stronger. From a geometric viewpoint, D1 and D3 are homoaxial. In the CIZ, D1 and D3 are designations formally applied to a deformation sequence where D2 refers to a syn-metamorphic deformation phase, dominantly non-coaxial, that can be constrained to have occurred between D1 and D3 (Noronha et al. 1971, Ribeiro 1974).

The staurolite-bearing micaschists of the PVMB show a schistosity ( $\mathrm{Sn}$ ) and a former metamorphic foliation (Sn-1) inside microlithons (Fig. 4a). Sn is pervasive along all the length of the 
PVMB and represents the main schistosity in which is frequent the presence of a mineral lineation along the maximum dip of the foliation plane, typically plunging to NE-ENE (Fig. 2). Sn-1 tends to be interpreted as a $\mathrm{S} 1$ cleavage and $\mathrm{Sn}$ as $\mathrm{S} 2$.

The superposition of D3 effects is common in the PVMB and in the adjacent low-grade rocks. This is particularly noticeable in the sectors of the PVMB that are closer to large-scale D3 structures, such as the Porto - Tomar Shear Zone (Oliveira de Azeméis sector; Fig. 2, stereogram E3) and the Juzbado - Penalva do Castelo Shear Zone (Viseu-Penalva do Castelo sector; Fig. 2, stereograms D1-3). In fact, in the latter, it is possible to follow the axial plane of the regional D3 macrofolds crossing the geological contact between the high-grade rocks of the PVMB and the low-grade rocks of the CIZ. This allows the interpretation of a common deformation history of the PVMB and the adjacent CIZ starting at D3, but a possible distinct deformation history during D1 and D2 (Dias et al., 2013).

\subsection{Kinematic interpretation and flow of the orogenic deformation}

In the CIZ low-grade metasedimentary rocks, the finite strain lineations are frequently represented by a faint mineral lineation in the S1 slaty cleavage and are envisaged, in most of the kinematic interpretations, as the maximum finite stretching of D1. The ductile flow in the CIZ slate belt involves shortening perpendicular to the orogenic trend with lateral escape, together with coeval movements along discrete shear zones parallel to the orogenic trend. Therefore, the tectonic regime responsible for this geometric and kinematic pattern is clearly contraccional or transpressive. This is very well documented in several key works (e.g.: Dias \& Ribeiro 1994; Ribeiro et al. 1990; Dias et al. 2013).

In the PVMB, it is impossible to reconstitute D1 kinematics, largely because D2 transposes almost completely any previous strain fabric. Sn schistosity, striking NW-SE to NNW-SSE and dipping to NEENE usually shows a mineral lineation along the dip direction (Fig. 2). This schistosity, in large sectors of the PVMB shows a high degree of non-coaxiality, which can be proved by several indicators of shear induced vorticity along the schistosity planes, such as $\mathrm{C} / \mathrm{S}$ structures and porphyroclastic systems developed from staurolite crystals (Fig. 4b-c). The intersection lineation of $\mathrm{C} / \mathrm{S}$ planes are perpendicular to the mineral lineation referred above. In the field, it is possible to recognize strain intensity gradients which culminate in bands of mylonites (Fig. 4d). In the NE boundary of the PVMB, the kinematic indicators in the L-S mylonites show top to the NE movement (Fig. 4b-c), whereas in the SW boundary 
of the PVMB (in the Oliveira de Azeméis region) was observed top to the SW movement in the mylonitic fabrics (Fig. 4e-f). However, in both cases, the schistosity planes are inclined to the NE, implying that the NE boundary has an inferred normal kinematics, whereas the SW boundary has reverse kinematics. In both boundaries delimiting the PVMB, the Dn variscan mesostructures (outcrop scale), markedly non-coaxial, exhibit the same metamorphic grade and high synkinematic field gradient. Therefore, despite the seemingly antithetical shear movement in the NE and SW mylonitic zones bordering the PVMB, the tectonic activity along those structures is coeval.

In summary, the bulk kinematics in the PVMB shows a pervasive deformation event dominated by a strong component of non-coaxial strain represented by the mylonitic shear zones with sense of movement perpendicular to the orogenic trend, independently of the tectonic regime responsible for D2 - extensional or contraccional (see discussion below). Therefore, the two major shear zones responsible for the bulk kinematics interpreted as D2 in the PVMB, correspond to the geological boundaries of the PVMB's anatectic complex.

\section{METAMORPHISM OF THE PORTO - VISEU METAMORPHIC BELT}

\subsection{Field observations and petrography}

The PVMB is mostly composed of schist-greywacke metasedimentary undifferentiated sequences, displaying a wide range of tectonometamorphic features and grades, and associated granitoids. Compared to the Douro - Beiras Supergroup metasediments, the PVMB has a much more penetrative NW-SE schistosity and is substantially more deformed, particularly in the border sectors, where most of the strain associated to the exhumation was concentrated.

A typical metamorphic sequence of the PVMB includes, in a NE-SW cross section (Fig. 3): staurolite-bearing mylonitic schists (Fig. 5a-b), deformed sillimanite-bearing schists, metatexites (Fig. 5c), diatexites (Fig. 5d) and, finally, S-type granites within the core of the anatectic complex (Migmatite terminology as in Wimmenauer \& Brihni 2007). Deformation is more diffuse in the core of the anatectic complex and much more concentrated in the border areas, producing mylonites with substantial retrograde metamorphism. This overall pattern can be occasionally disturbed by the emplacement of late-orogenic granites, such as the Castro Daire or Cota granites. The latter granitic massif was emplaced from 299 to $296 \mathrm{Ma}$ (Valle Aguado et al. 2017). The PVMB is, therefore, composed of rocks that show 
a distinct tectono-metamorphic evolution from the regional low-grade schist-greywacke complex of the host CIZ, suggesting a separate P-T evolution with later juxtaposition from which resulted the aforementioned "temperature jump" (Valle Aguado et al. 2010; Pereira et al. 2017a).

In the PVMB, from NW, near Porto, to SE, near Viseu, several migmatitic rocks are emplaced onto the host low-grade rocks of the CIZ (see location of studied sectors in Fig 2). In the Porto sector of the PVMB, high-grade metamorphic rocks are well documented, such as the Mindelo Migmatite Complex and the Pedregal Migmatitic Complex (e.g.: Ferreira 2013a; Ferreira et al. 2014; Silva 2014; Ribeiro et al. 2014). The Mindelo Migmatite Complex is exposed in the coastal area North of Porto, presenting a substantial lithological heterogeneity composed of unmigmatized metagreywackes, calcsilicate rocks that remain as resisters, patchy metatexites, stromatic metatexites, diatexites, leucogranites and S-type two-mica granites (Silva 2014). The migmatitic rocks are emplaced onto the Douro - Beiras Supergroup low-grade metapelites and metagreywackes that are dominant to the NE. The PVMB's NE boundary separates the migmatitic complex from the low-grade rocks. The typical metamorphic gradient from East to West (near the coast) increases from: a) chlorite and biotite zones, displaying the low-grade phyllites and metagreywackes of the host Douro - Beiras Supergroup; b) staurolite and sillimanite zones with staurolite- and sillimanite-bearing schists; and c) sillimanite + K-feldspar zone with the appearance of different types of migmatites and S-type granites (Areias et al. 2013). The patchy metatexites show anastomosed foliation given by the alignment of biotite intergrown in a $\mathrm{Qz}+\mathrm{Pl} \pm$ Grt assemblage (all mineral abbreviations are presented as in Whitney \& Evans 2010). Garnet is completely or partially replaced by $\mathrm{Crd}+\mathrm{Qz}+$ Sill. The stromatic metatexites display melanosomes with $\mathrm{Bt}+\mathrm{Sil}+\mathrm{Crd}+\mathrm{Grt}$ $+\mathrm{Qz}+\mathrm{Pl}$, whereas the leucosomes are quartz-feldspathic bands $(\mathrm{Qz}+\mathrm{Pl}+\mathrm{Kfs}+\mathrm{Bt})$. Diatexites consist of an isotropic assemblage of $\mathrm{Qz}+\mathrm{Pl}+\mathrm{Kfs}+\mathrm{Bt}+\mathrm{Sil}+\mathrm{Crd} \pm \mathrm{Grt}$. Leucogranites are composed by $\mathrm{Qz}$ $+\mathrm{Pl}+\mathrm{Kfs} \pm \mathrm{Bt} \pm$ Tur, whereas the two-mica granites show several signs of the genetic relationship with the migmatites, being composed by $\mathrm{Qz}+\mathrm{Pl}+\mathrm{Kfs}+\mathrm{Bt}+\mathrm{Ap}$ and rare schlieren of $\mathrm{Bt}+\mathrm{Sil} \pm \mathrm{And} \pm \mathrm{Grt}$ \pm Zrn (Areias et al. 2013). Regarding migmatitic rocks, in the Pedregal Migmatitic Complex there is a similar lithological composition, being mostly comprised of diatexites and metatexites, and minor staurolite-bearing micaschists and syn-orogenic two-mica granites. The diatexites comprise $\mathrm{Qz}+\mathrm{Pl}+$ $\mathrm{Kfs}+\mathrm{Bt}+\mathrm{Ms}+\mathrm{Zrn}+\mathrm{Ap}+\mathrm{Mnz}+\mathrm{Rt} \pm \mathrm{Sil} \pm \mathrm{Zn}$-rich hercynite (Fig. 6a) and, locally, exhibit biotitic selvedges and metasedimentary enclaves (Fig. 6b). The metatexites mineral assemblage is $\mathrm{Qz}+\mathrm{Pl}+$ 
$\mathrm{Kfs}+\mathrm{Bt}+\mathrm{Ms} \pm \mathrm{Grt}$ (Ferreira 2013a; Ferreira et al. 2015). These rocks reveal a stromatic texture where the quartz-feldspathic neosomes alternate with the mica-rich paleosomes. Concerning the metamorphic conditions, this part of the sector is completely located within the anatectic core of the PVMB and is dominated by migmatites, mostly diatexites. Therefore, previous works on this sector do not report the low-grade metamorphic rocks of the Douro - Beiras Supergroup, located further to the East (about $2 \mathrm{~km}$ from Pedregal; Fig. 2; sector A). There, the metamorphic grade increases quickly from the typical chlorite/biotite phyllites of the host Douro - Beiras Supergroup to the staurolite/sillimanite zones of the PVMB (Ribeiro et al. 2015), being these two crustal domains separated by a discrete shear zone, the PVMB's NE boundary shear zone.

In the Foz do Sousa sector (Ferreira 2013b), near the NE boundary of the PVMB (Fig. 2; sector B), it is possible to find the lowest grade rocks of this anatectic complex. Metapelites are the most common lithological type in this sector, displaying, from East to West: a) chlorite zone metagreywackes and phyllites composed of $\mathrm{Qz}+\mathrm{Ms}+\mathrm{Chl}+\mathrm{Ab}+\mathrm{Ilm} \pm \mathrm{Bt} \pm$ Tur \pm Ep with the entire mineral assemblage placed within a grano-lepidoblastic texture; b) biotite zone phyllites and schists composed of a $\mathrm{Qz}+\mathrm{Ab}$ $+\mathrm{Bt}+\mathrm{Ms}+\mathrm{Chl}+\mathrm{Ilm} \pm$ Tur mineral assemblage. Biotite is occasionally present as large mica-fish porphyroclasts intersecting the grano-lepidoblastic texture, whereas the remaining minerals are placed within the schistosity planes; and c) garnet-staurolite micaschists composed of a $\mathrm{Qz}+\mathrm{Pl}+\mathrm{Ms}+\mathrm{Bt}+$ St + Grt \pm And \pm Ilm \pm Tur mineral assemblage (Fig. 7a). Staurolite and garnet are present as large porphyroclasts (M1 metamorphic peak), depicting abundant deformation features (pressure shadows, anhedral crystal formation and cracks), whereas andalusite porphyroblasts are typical of the late retrogressive M2 assemblage replacing staurolite. Millimetric bands of $\mathrm{Bt}+\mathrm{Ms}$ involving and replacing Grt + St are the most common M2 paragenesis (Fig. 7a), depicting a two-stage decompression/cooling events: a) garnet replacement by retrogressive $\mathrm{Bt}+\mathrm{St}$; followed by b) late Ms formation after staurolite. In this sector, the garnet-staurolite micaschists of the PVMB are separated from the lower grade chloriteand biotite-phyllites of the Douro - Beiras Supergroup by the PVMB's NE boundary shear zone. Deformation is very strong in the staurolite-bearing micaschists, being visible that the main schistosity planes always surrounds the staurolite and garnet porphyroclasts (Fig. 6c).

Further SE, in Serra da Freita sector (Fig. 2; sector C) the most common rocks are mylonitic schists with large (up to $15 \mathrm{~cm}$ ) porphyroclasts of staurolite (Reavy et al. 1991; Acciaiolli et al. 2005). 
In this sector, the metasedimentary sequences are mostly composed of metapelites and are characterized, from NE to SW, as: a) chlorite-biotite phyllites and schists of the Douro - Beiras Supergroup, presenting $\mathrm{a} \mathrm{Qz}+\mathrm{Chl}+\mathrm{Ms} \pm \mathrm{Bt} \pm \mathrm{Pl}$ assemblage; b) below these rocks, separated by the same major shear zone referred in Foz do Sousa Sector, there is a greywacke-pelitic sequence of mylonites with centimetric staurolite porphyroclasts (Fig. 6d). The mineral assemblage is typically $\mathrm{Qz}+\mathrm{Pl}+\mathrm{Ms}+\mathrm{Bt}+\mathrm{St} \pm \mathrm{Ky} \pm$ $\mathrm{Ilm}$, whereas the sillimanite-bearing schists display $\mathrm{Qz}+\mathrm{Pl}+\mathrm{Ms}+\mathrm{Bt}+\mathrm{And}+\mathrm{St}+\mathrm{Sil}+\mathrm{Ilm}+\mathrm{Zrn}$. Staurolite and kyanite growth is coeval during M1, whereas retrogressive stage M2 included the replacement of staurolite by $\mathrm{Bt}+\mathrm{And} / \mathrm{Sil}$ (Acciaiolli et al. 2005); c) metatexites with $\mathrm{Qz}+\mathrm{Pl}+\mathrm{Bt}+$ $\mathrm{Kfs}+\mathrm{Sil} \pm \mathrm{Ms} \pm \mathrm{St} \pm$ And (Fig. 7b-c); and, finally, d) the Serra da Freita two-mica granites. These are S-type granites with isotopic signatures relatable with the anatectic complex rocks (Reavy et al. 1991).

The Viseu - Penalva do Castelo sector (Fig. 2, sector D) is probably the best studied sector of the PVMB, particularly in recent years (Oen 1958; 1970; Gonçalves et al., 1990; Esteves 2006; Valle Aguado \& Azevedo 2006; 2010; Ferreira et al. 2009; 2010, Sousa, 2013). In this sector, the metamorphic pattern given by D2 is substantially folded by the later D3 JPCSZ, which makes it harder to visualize and interpret. However, the metasedimentary sequences, essentially composed of metapelites (with minor metapsammites and metagreywackes) display an overall pattern characterized, from NE to SW and top to bottom, as the following: a) phyllites and chlorite-biotite schists incipiently deformed, presenting: i) in the chlorite zone, $\mathrm{Qz}+\mathrm{Ab}+\mathrm{Chl}+\mathrm{Ms}+\mathrm{Ilm}$; ii) in the biotite zone, $\mathrm{Qz}+\mathrm{Ab}+\mathrm{Bt}+$ $\mathrm{Chl}+\mathrm{Ms}+\mathrm{Ilm}$. These rocks are part of the Douro-Beiras Supergroup metasedimentary sequence and are always placed immediately NE of the PVMB's NE boundary shear zone; b) mylonites (Fig. 4d) with centimetric porphyroclasts of staurolite (similar to Serra da Freita sector), sillimanite-bearing schists and migmatites (both metatexites and diatexites, including the previously labelled Cavernães Granite; Valle Aguado et al. 2010). These rocks present the following metamorphic zones, from NE to SW: i) staurolite zone, depicting a $\mathrm{Qz}+\mathrm{Pl}+\mathrm{Ms}+\mathrm{Bt}+\mathrm{St} \pm \mathrm{Grt} \pm \mathrm{And} \pm \mathrm{Gr} \pm \mathrm{Ilm}$ mineral assemblage; ii) sillimanite zone, depicting a $\mathrm{Qz}+\mathrm{Pl}+\mathrm{Ms}+\mathrm{St}+\mathrm{Sil}+\mathrm{Ilm} \pm \mathrm{Bt} \pm \mathrm{And} \pm \mathrm{Gr}$ mineral assemblage; iii) sillimanite + K-feldspar zone with a mineral assemblage composed of Qz + Pl + Ms + Kfs + Sil + Ilm $\pm \mathrm{St} \pm \mathrm{And} \pm \mathrm{Gr}$ in metatexites (Fig. $7 \mathrm{~d}-\mathrm{e})$, and $\mathrm{Qz}+\mathrm{Pl}+\mathrm{Tr}+\mathrm{Ttn} \pm \mathrm{Di} \pm \mathrm{Ilm} \pm \mathrm{Cal} \pm \mathrm{Grt} \pm \mathrm{Ms} \pm \mathrm{Ol} \pm$ Ap in interlayered calc-silicate rocks (Fig. 7f). Diatexites present a mineral assemblage similar to the metatexites, although with a more substantial proportion of felsic minerals $(\mathrm{Qz}+\mathrm{Pl}+\mathrm{Kfs})$ and minor 
or absent hydrous minerals, such as muscovite and biotite. In fact, in diatexites, muscovite is only present in the retrograde mineral assemblage (Fig. $7 \mathrm{~g}$ ). Additionally, kyanite has been observed in interlayered metagreywackes (Atherton et al. 1974; Esteves 2006) near the staurolite-bearing schists and mylonites, but its placement within the sequence is still difficult to make. In summary, this sector presents the lowgrade metasedimentary sequence of the CIZ on top, separated by the PVMB's NE boundary shear zone from a Barrovian-type metamorphic sequence with the development of migmatites within the core of the anatectic complex. Transition from the lower grade metamorphic rocks (chlorite-biotite schists) to the higher grade rocks (diatexites) occurs very abruptly $(1000-2000 \mathrm{~m})$ and always with the metamorphic zones being separated by discrete shear zones. In this sector, the overall metamorphic pattern is occasionally disturbed by late granite intrusions (e.g.: Cota granite) and folding (sub-vertical axial planes) related to the activity of the nearby Juzbado - Penalva do Castelo Shear Zone, whose continuous activity until the end of the D3 events folded the SE extremity of the PVMB, including the PVMB's NE boundary shear zone (Pereira et al. 2017a; Valle Aguado et al. 2017), where the Viseu Penalva do Castelo sector is located. Post-peak retrogressive metamorphism also leads to a more complex metamorphic pattern. Several features of retrogressive metamorphism associated to the exhumation process are visible: prismatic andalusite (chiastolite) pseudomorphs after staurolite porphyroclasts (Fig. 6e) and And + Bt coronas surrounding staurolite (Esteves 2006; Bento dos Santos 2010). These textural evidences are associated to the reorientation of the staurolite porphyroclasts from sub-horizontal to sub-vertical and late anatexis of these rocks by decompression, which produces millimeter-thick veinlets (Fig. 6f) that intersect the schistosity/mylonitic planes (Valle Aguado \& Azevedo 2006). Sillimanite-bearing schists and migmatites typically show replacement of sillimanite by the Ms + Qz M2 assemblage. This late replacement is less pronounced in areas where melt extraction occurred, leaving the rocks dehydrated and less able to form hydrous phases during retrogressive metamorphism (as in Spear et al. 1999; Bento dos Santos et al. 2011b).

In the least studied SW border of the PVMB (Fig. 2, sector E), the Oliveira de Azeméis sector 345 (Pereira et al. 2005), a cross section from NE to SW shows the opposite pattern from all previously described sectors: S-type granites and diatexites (Fig. 7h), such as the Freita diatexite (Serra da Freita granite; Reavy et al. 1991) in the NE, showing a gradual transition to metatexitic rocks with $\mathrm{Qz}+\mathrm{Pl}+$ $\mathrm{Bt}+\mathrm{Kfs}+\mathrm{Sil} \pm \mathrm{Ms} \pm \mathrm{St} \pm$ And and sillimanite/staurolite-bearing schists and mylonites, further to SW. 
This pattern is not continuous, but occasionally repeated or interrupted. To the SW, the PVMB's SW boundary shear zone separates the high-grade complex from the chlorite schists and phyllites of the Douro - Beiras Supergroup and a syn-D3 large pluton that was emplaced at the boundary shear zone (Fig. 2). In this sector, the anatectic complex of the PVMB is delimited by the SW boundary shear zone, a tilted D2 thrust that shows movement of the top to SW in metatexitic mylonites (Fig. 4e). This structure imprints a strong sub-horizontal foliation in many of the high-grade rocks of the anatectic complex, namely in the syn-orogenic Castanheira Granite (Pedra Parideira Geosite near Arouca; Fig. 4f), a famous geological site for nodular biotite, formed by the retrogression of the metamorphic peak paragenesis during exhumation.

The PVMB's metamorphism is complex and can only be fully understood when linked together. Overall, the PVMB is composed of high- to very high-grade metamorphic rocks and anatectic granites, delimited by 2 major shear zones and inserted within a low- to very low-grade metamorphic autochthonous metasedimentary sequence. In a NE - SW cross section (Fig. 3), it is possible to find: a) the metasedimentary Douro Group low-grade slate belt (Sá et al. 2014); b) the PVMB's NE boundary shear zone (normal kinematics), followed by a sharp metamorphic increase to staurolite-bearing and sillimanite-bearing schists; c) the anatectic core, composed of metatexites (Sil + Kfs zone), diatexites (Ms-out) and anatectic plutons; d) the PVMB's SW boundary shear zone (reverse kinematics), delimiting the NE-tilted PVMB; and e) the metasedimentary Beiras Group low-grade slate belt (Pereira et al. 2005), occasionally placed below the PVMB's SW boundary shear zone with high-grade metamorphic rocks and anatectic plutons on top, rooted to the SW border of the PVMB. Although they will not be further discussed in this work, also present in the PVMB and surrounding region, are later D3 granites (e.g.: Cota and Castro Daire granites) that intersect the area and cause late-stage (M3) contact metamorphism. The M3 typical features include overprinting of the metamorphic assemblages previously presented by (mostly) large biotite and andalusite porphyroblasts. These features are present in every studied sector, but their influence in the metamorphic pattern is limited, localized and always possible to clearly define (see contact metamorphism isograds in Ferreira et al., 2009, for instance). Because the M3 stage is very late in the geological evolution of the PVMB and out of scope of this work, we excluded from this study all samples located in the contact metamorphic aureole of an intrusion or that had any feature caused by the M3 contact metamorphism. 


\subsection{Mineral Chemistry}

380

The PVMB is mostly composed of migmatites (diatexites and metatexites) and granites, being the presence of unmigmatized rocks exclusive of the borders delimiting the belt. One of these samples (P11a, location in Fig. 1), a garnet-staurolite micaschist from Foz do Sousa sector was chosen for geothermobarometric studies, mainly for 2 reasons: a) it has the most appropriate mineral assemblage for P-T estimation, namely the presence of garnet; b) this rock represents the lowest temperature rocks of the anatectic complex, being in close proximity (less than $100 \mathrm{~m}$ ) to the low-grade sequence of the CIZ. P-T estimates on this rock allows to quantify the temperature jump associated to the activity of the shear zone that separates the NE border of the anatectic complex (this sample) and the low-grade metasedimentary sequence present in the host CIZ. Samples from the migmatite units in the Viseu sector were also selected for geothermobarometry, namely a metatexite (sample A2, location in Fig. 1) and a calc-silicate rock interlayered in the metatexites (sample 17A, location in Fig. 1). Quantitative results for the metatexites will be provided below, as well as an approximate estimate on the metamorphic peak conditions within the anatectic core (the diatexites).

Mineral chemistry data obtained in these samples are summarized in Tables 1-3 and expanded in Supplementary File 1 ( 470 EPMA analyses for sample A2, 17A and P11a).

As previously mentioned, the garnet-staurolite micaschist (P11a) is composed of a Qz $+\mathrm{Pl}+\mathrm{Ms}$ $+\mathrm{Bt}+\mathrm{St}+\mathrm{Grt} \pm$ And $\pm \mathrm{Ilm} \pm$ Tur mineral assemblage with an $\mathrm{M} 1$ paragenesis composed of $\mathrm{Qz}+\mathrm{Pl}+$ $\mathrm{St}+\mathrm{Grt}+\mathrm{Bt}$, whereas the M2 paragenesis includes the formation of And $+\mathrm{Ms}+\mathrm{Bt}$ from the breakdown of $\mathrm{St}+\mathrm{Grt}+\mathrm{Pl}$ rims. This petrographic observation was taken into account for the mineral chemistry analysis and the geothermobarometric estimates. Chemical profiles in garnet (e.g.: Fig. 8a) reveal they are essentially almandines $\left(\mathrm{X}_{\mathrm{Alm}}=0.71-0.78\right)$ with $\mathrm{X}_{\mathrm{Prp}}=0.09-0.12, \mathrm{X}_{\mathrm{Grs}}=0.04-0.06$ and $\mathrm{X}_{\mathrm{Sps}}=$ $0.04-0.13$, presenting a small zoning pattern from rim to core, but limited to the initial $10 \mu \mathrm{m}$ and related to the M2 retrogressive stage. In the rim area, garnet is typically enriched in almandine, but depleted in pyrope. No signficant difference is visible for grossular, and spessartine contents are commonly $\sim$ 0.1. Core and rim analysis of staurolite (e.g.: Fig. 8a-b) show an enrichment in Fe $\left(\mathrm{X}_{\mathrm{FSt}}=\right.$ $0.81-0.83$ ) with a very limited zoning pattern, being the staurolite cores enriched slightly in Fe. The small chemical zoning of staurolite is surprising if the size of the porphyroclasts is considered. However, 
its crystal structure has lower retentivity than garnet which can explain the difference in chemical zoning. Plagioclase is a typical oligoclase with $\mathrm{X}_{\mathrm{An}}=0.14-0.18$, displaying a small enrichment of the anorthite content from core to rim, probably related to a slightly higher affinity of $\mathrm{Ca}$ to grossular at higher temperatures. Biotites have $\mathrm{X}_{\mathrm{Ann}}=0.54-0.58$ and display no chemical zoning, which is typical of the low retentivity structure of micas, as well as the presence of these minerals in the M2 retrogressive paragenesis. White mica, however, formed exclusively during $\mathrm{M} 2$ shows $\mathrm{X}_{\mathrm{Ms}}=0.69-0.79$ and $\mathrm{X}_{\mathrm{Prg}}=$ 0.20-0.29. This higher chemical variation in white micas with no chemical zoning is probably related to a prolonged period of white mica formation during the M2 retrogressive stage with extensive cooling after the metamorphic peak where diffusion in micas was still possible.

Identical work was performed for the other 2 samples, each with 2 polished thin sections (A2-1, A2-2, 17A-1, 17A-2). Metatexite sample (A2) is composed of a $\mathrm{Qz}+\mathrm{Pl}+\mathrm{Bt}+\mathrm{Kfs}+\mathrm{Sil}+\mathrm{Grt}+\mathrm{Ilm}$ assemblage, whereas the interlayered calc-silicate rock sample (17A) is composed of $\mathrm{Qz}+\mathrm{Pl}+\mathrm{Ttn}+$ $\mathrm{Grt}+\mathrm{Di}+\mathrm{Ilm}+\mathrm{Cal}+\mathrm{Ap}$ assemblage. Mineral chemistry of the metatexite (Table 2) has some similarities with the staurolite-bearing schist P11a. Metatexites also have garnets that are essentially almandines $\left(\mathrm{X}_{\mathrm{Alm}}=0.808-0.844\right)$ with $\mathrm{X}_{\mathrm{Prp}}=0.084-0.133, \mathrm{X}_{\mathrm{Grs}}=0.02-0.03$ and $\mathrm{X}_{\mathrm{Sps}}=0.03-0.04$. Plagioclase is typically an oligoclase, although a larger variation is also common $\left(\mathrm{X}_{\mathrm{An}}=0.05-0.26\right)$, whereas K-feldspar, only present in the metatexite, has $\mathrm{X}_{\mathrm{Ort}}=0.80-0.93$ and $\mathrm{X}_{\mathrm{Ab}}=0.08-0.19$. Biotites have higher $\mathrm{Mg} \#=0.371-0.407$ and higher $\mathrm{TiO}_{2}=3.3-4.3 \mathrm{wt} \%$.

The calc-silicate sample (Table 4) has, as expected, a plagioclase that is an almost pure anorthite $\left(X_{\mathrm{An}}=0.92-0.98\right)$, diopsides with $\mathrm{X}_{\mathrm{Ens}}=0.27-0.36, \mathrm{X}_{\mathrm{Fsl}}=0.14-0.24$ and $\mathrm{X}_{\mathrm{Wo}_{\mathrm{o}}}=0.48-0.50$ and garnets rich in grossular-almandine components, with $\mathrm{X}_{\mathrm{Grs}}=0.45-0.55, \mathrm{X}_{\mathrm{Alm}}=0.35-0.43, \mathrm{X}_{\mathrm{Prp}}=0.02$ -0.06 and $\mathrm{X}_{\mathrm{Sps}}=0.06-0.13$.

\subsection{Geothermobarometry}

Average P-T calculations obtained with the THERMOCALC software, v. 3.33 (Holland \& Powell 1998) take into account the petrographic observations referred above and make use of a wide set of independent reactions involving all end-members for the defined mineral assemblages considered in equilibrium. THERMOCALC also provides a statistical estimate of the equilibrium attained by the analysed minerals and allows significant iteration to minimize uncertainty. Standard deviation for the reactions controlling 
the P-T outputs were $15-60{ }^{\circ} \mathrm{C}$ and $0.9-1.6 \mathrm{kbar}$, being the overall correlation of the independent set of reactions always above 0.8 , confirming the chemical equilibrium of the analysed mineral assemblages.

Petrography and mineral chemistry results obtained for the studied samples allowed the individualization of the mineral parageneses consistent to the metamorphic peak conditions M1, as well as the typical mineral parageneses associated to the retrogressive stage M2, which, according to each sample/lithology, was: a) garnet-staurolite micaschist sample P11a: M1 - cores of Grt-St-Pl + matrix Bt + Qz; M2 - rims of Grt-St-P1 + nearby Bt-Ms + Qz-And; b) metatexite A2: M1 - cores of Grt-Pl-Ilm + matrix Bt + Qz-Sil; M2 - rims of Grt-Pl-Ilm + nearby Bt + Qz; and c) calc-silicate rock 17A: M1 - cores of Grt-Di-Pl-Ilm + Qz; M2 - rims of of Grt-Di-Pl-Ilm + Qz.

The integrated use of this information with the aid of the THERMOCALC software, v. 3.33 (Holland \& Powell 1998) in garnet-staurolite micaschist sample P11a provided P-T results for the M1 stage at $\mathrm{P}=5.7 \mathrm{kbar}$ and $\mathrm{T}=635^{\circ} \mathrm{C}$, and $\mathrm{P}=4.9 \mathrm{kbar}$ and $\mathrm{T}=437^{\circ} \mathrm{C}$ for the $\mathrm{M} 2$ stage. For metatexite A2 (sub-samples 1 and 2), results at $\mathrm{P}=7.7-7.9$ kbar and $\mathrm{T}=769-780^{\circ} \mathrm{C}$ for the $\mathrm{M} 1$ stage and $\mathrm{P}=$ $5.9-6.2 \mathrm{kbar}$ and $\mathrm{T}=545-560^{\circ} \mathrm{C}$ for the $\mathrm{M} 2$ stage were obtained, whereas the calc-silicate rock $17 \mathrm{~A}$ (sub-samples 1 and 2) provided $\mathrm{P}=7.6 \mathrm{kbar}$ and $\mathrm{T}=796-812^{\circ} \mathrm{C}$ for $\mathrm{M} 1$ and $\mathrm{P}=3.5-5.4 \mathrm{kbar}$ and $\mathrm{T}$ $=421-512^{\circ} \mathrm{C}$ for the M2 stage. These are the first reliable and quantitative P-T estimates in the PVMB (Fig. 9; Table 4).

These results imply a $200{ }^{\circ} \mathrm{C}$ drop associated to the retrogression and initial exhumation of the garnet-staurolite micaschists from higher depths to shallower levels, including a minimum $1 \mathrm{kbar}$ decompression, which is the equivalent to $\sim 3 \mathrm{~km}$ uplift. As previously mentioned, these results do not represent the metamorphic peak conditions of the anatectic complex, but of its border sectors where sample 11a was collected. If the maximum temperature $\left(\sim 630^{\circ} \mathrm{C}\right)$ obtained for this sample can be considered close to its metamorphic peak, the M2 retrogressive temperature $\left(\sim 430^{\circ} \mathrm{C}\right)$ most likely represents the overall metamorphic peak temperature or, at least, a close estimate for the P-T conditions attained by the phyllites and biotite-schists of the Douro - Beiras Supergroup during the Variscan Orogeny (Fig. 9). Also important is the overall P-T estimate for the metatexite (and interlayered calcsilicate rock) which included a metamorphic peak at $\mathrm{P} \sim 8 \mathrm{kbar}$ and $\mathrm{T} \sim 800^{\circ} \mathrm{C}$, which is consistent to the P-T conditions typically attained by these rocks in a Barrovian metamorphism setting. Again, this 
estimate, although does not represent the metamorphic peak of the anatectic complex, already provides a close quantitative approach.

\section{DISCUSSION}

A strong contrast of the ductile material flow deformation between the PVMB and the host CIZ autochthonous rocks is present, being the PVMB envisaged as an independent block delimited by 2 major crustal-scale shear zones. The new geothermobarometric data supports this tectonic interpretation. The P-T estimates for the unmigmatized rocks of the PVMB confirm a minimum temperature drop of over $200{ }^{\circ} \mathrm{C}$ from the border of the anatectic complex to the host metasedimentary sequence. The latter should not have surpassed $\mathrm{T}=430{ }^{\circ} \mathrm{C}$, as can be roughly estimated by the presence of phyllites and schists with biotite as its metamorphic index minerals and the absence of any other high-temperature minerals, such as garnet, andalusite, kyanite or staurolite. However, the temperature drop from the core of the anatectic complex to the host rocks must have been substantially higher (Fig. 9).

Petrographic analysis of the metatexites suggest dehydration-melting of muscovite to form peritectic Sil + Kfs, a typical feature for metatexites (e.g. Spear et al. 1999; Anenburg \& Katzir 2014), particularly at $\mathrm{T}>700{ }^{\circ} \mathrm{C}$ (Vielzeuf \& Holloway 1988; Bento dos Santos et al. 2011b). If metatexites are typical of incipient crustal anatexis, diatexites represent the more advanced stages of migmatization at even higher temperatures, reason why their presence in the anatectic cores is so common. Diatexite formation in metapelites implies substantial melting, typically in the minimum range of $30-40 \%$ melt fraction (Millord et al. 2001; Sawyer 2008; Bento dos Santos et al. 2011b) and is usually caused by biotite dehydration-melting (e.g.: Clemens \& Vielzeuf 1987; Stevens et al. 1997; Sawyer et al. 2011). Evidence for biotite dehydration-melting points out to $\mathrm{T}>750^{\circ} \mathrm{C}$ (Vielzeuf \& Holloway 1988) and the presence of diatexites representing melt fraction over $30 \%$ implies $\mathrm{T}>800{ }^{\circ} \mathrm{C}$ (Patiño Douce \& Beard 1995; Bento dos Santos et al. 2011b). However, the petrographic observation that biotite is not completely exhausted in the PVMB diatexites, constrains the metamorphic peak temperature at $800<\mathrm{T}$ $<830^{\circ} \mathrm{C}$ (Vielzeuf \& Holloway 1988; Patiño Douce \& Beard 1995), which is very close to the maximum estimate obtained for the calc-silicate sample interlayered in the metatexites $\left(\mathrm{T}=812{ }^{\circ} \mathrm{C}\right)$, located very close to the Cavernães diatexite. High Ti contents $(>4.0 \mathrm{wt} \%)$ in biotites from the migmatites are in good agreement with this statement. The sporadic observation of Zn-rich hercynite in Pedregal, located 
at the anatectic core of the PVMB in Porto sector, may imply even higher metamorphic peak temperatures. The process of metapelite melting at depth is gradual and reflects the transition from migmatites to the formation of large voluminous S-type granites. Indeed, transition from diatexites to granites is so gradual and, many times, subjective that only recently some of the syn-orogenic granites previously identified within the PVMB have been labelled as diatexites due to their distinctive textural features. This is the case at Cavernães (Valle Aguado et al. 2010), Pedregal (Ferreira et al. 2015; 2016) and Mindelo (Silva 2014) and probably for the Serra da Freita pluton, as previously suggested with geochemical data by other authors (e.g.: Reavy et al. 1991).

As previously mentioned, the mineralogy of the metapelite sequence present in several sectors of the PVMB, namely staurolite and kyanite, suggests a M1 Barrovian-type prograde metamorphic sequence (Valle Aguado et al. 2010; Bento dos Santos 2010; Azevedo \& Valle Aguado 2013), with a geothermal gradient of $\sim 30{ }^{\circ} \mathrm{C} / \mathrm{km}$. This agrees well with the obtained P-T estimates of the garnetstaurolite micaschist of $\mathrm{T}=635^{\circ} \mathrm{C}$ at $\mathrm{P}=5.7 \mathrm{kbar}$ and for the metatexite samples $\left(\mathrm{T}=769-812^{\circ} \mathrm{C} ; \mathrm{P}\right.$ $=7.6-7.9 \mathrm{kbar})$. For a typical geostatic gradient of $3.7 \mathrm{~km} / \mathrm{kbar}$, the estimated depth of the staurolite schist P11a is $21.1 \mathrm{~km}$, corresponding to a geothermal gradient of $30.1{ }^{\circ} \mathrm{C} / \mathrm{km}$. For metatexites and diatexites in the core of the anatectic complex at $\mathrm{T}=800{ }^{\circ} \mathrm{C}$, considering the same geothermal gradient $\left(30.1^{\circ} \mathrm{C} / \mathrm{km}\right)$, the depth would be $26.6 \mathrm{~km}$. Considering the obtained results for samples A2 and 17A (P $=7.6-7.9 \mathrm{kbar}$ ) and a typical geostatic gradient of $3.7 \mathrm{~km} / \mathrm{kbar}$, the estimated depth is $28.1-29.2 \mathrm{~km}$ (average geothermal gradient of $28^{\circ} \mathrm{C} / \mathrm{km}$; Table 4). Rutile in the diatexites of Pedregal, Porto sector (Ferreira et al., 2013a) may even imply higher depths (Pereira et al. 2020 and references therein). The depth range estimated for the formation of the anatectic complex contrasts sharply with the depths at which the low-grade host rocks were formed (10 - $13 \mathrm{~km}$ depth; Pereira et al. 2017a), implying that a minimum 10 to $17 \mathrm{~km}$ vertical uplift of the anatectic complex occurred after M1. Evidence for this strong vertical uplift can be found in the retrogressive M2 metamorphic parageneses featuring chiastolite pseudomorphs of staurolite (Esteves 2006; Bento dos Santos 2010), in the textural evidence of latedecompressive melting of staurolite-bearing schists near Cavernães, in And + Bt coronas surrounding staurolite (Valle Aguado \& Azevedo 2006; Esteves 2006; Bento dos Santos 2010) and in the late replacement of Grt + St by Crd \pm Sil in Mindelo, Porto sector (Areias et al. 2013). This uplift was probably very fast, because M1 minerals show no significant chemical variation from core to rim, 
implying reduced diffusion during retrogression. The P-T results of the M2 assemblage for all lithotypes (Fig. 9) confirms substantial P-T drops, although there is a more consistent first stage with significant cooling, followed by a second stage that mostly included pressure drop. The temperature range for the M2 results (obtained with the rims of the peak minerals) reflect the closure temperatures for the cationexchange reactions, being this $\mathrm{T}$ range exactly between the staurolite-schist and the low-grade host rocks peak temperatures, the two lithotypes that are separated by the shear zones. These results are consistent with the petrographic observations and also the tectonic model proposed for the exhumation of the anatectic complex (see below).

The rationale presented above indicates that the Douro - Beiras Supergroup low-grade metamorphic sequence is a supracrustal sequence that defines the metamorphic base level of the CIZ, whereas the studied anatectic complex is a significantly hotter and deeper metamorphic sequence that was juxtaposed onto the host rocks by discrete shear zones. These are first-order structures that emplaced the anatectic complex onto shallower levels of the crust, namely with a vertical exhumation of 10 to 17 $\mathrm{km}$. However, the horizontal distance between the low-grade rocks and the anatectic core $\left(400^{\circ} \mathrm{C}\right.$ hotter) rarely exceeds $2 \mathrm{~km}$, being in most cases $\sim 1 \mathrm{~km}$, implying abnormal geothermal gradients of $>200$ ${ }^{\circ} \mathrm{C} / \mathrm{km}$ (Fig. 10). The metamorphic isograds are, thus, telescoped. This sharp transition can only be explained by a strong vertical displacement separating both sequences, i.e.: uplift and decompression of the anatectic complex onto the lower grade host rocks by the shear zones delimiting the PVMB. In fact, the uplift was mostly performed throughout the discrete boundary shear zones that exhibit substantial evidence of shear induced vorticity in the staurolite-bearing mylonitic bands bordering the PVMB.

The difference between horizontal distance and inferred depth within the anatectic complex, given by the telescoping of the isograds, can be explained by internal accommodation of shear strain along the lepidoblastic fabric previously generated during M1. In fact, it is possible to observe transposition of previous metamorphic (M1) foliations by D2 shear fabrics generated during the exhumation, which should correspond to the M2 episode. This type of strain and shear distribution within micro-scale foliation planes is consistent to the card deck model of simple shear (e.g.: Ramsay \& Huber 1987) and is typical of deformed/sheared metapelite sequences and part of the proposed exhumation model for the PVMB (see below). 
The PVMB's mylonites display a down-dip lineation (Fig. 2), interpreted as the slip direction, which implies movement perpendicular to the orogenic trend and explains the referred P-T evolution. However, this kinematics has been interpreted as resulting from extensional tectonics (e.g.: Valle Aguado et al. 2005) due to the top to the NE movement in the NE border of the PVMB. However, considering that the host low-grade rocks are dominant in the CIZ and represent its metamorphic base level, it is unlikely that such an immense block would detach along the NE boundary shear zone. Such collapse would also imply the preservation of a continuous metamorphic pattern from low-grade to highgrade metamorphic rocks, which is not the case in the PVMB. The PVMB's plastic flow, perpendicular to the orogenic trend and vergent to SW, reveals both $\mathrm{D} 2$ normal and reverse kinematics within the belt, mostly concentrated by the two crustal-scale boundary shear zones. An integrated view for the exhumation of the PVMB must also take into account the movement and kinematics of the shear zone delimiting the SW border of the PVMB. Comparing it to the NE border, the SW border has an antithetical kinematics, which is hard to explain with an extensional detachment. Considering that these ductile shear zones are coeval and contributed to the exhumation of the PVMB, a more complete pattern emerges. Instead of considering an individual movement of both shear zones, if both moved to exhume the PVMB, it is feasible to fix the host low-grade rocks, which are less deformed, and to concentrate the movement (and exhumation) within the belt itself. This idea is much more consistent to the observation that it is within the PVMB that most of the D2 non-coaxial deformation is concentrated. Besides, because migmatites are partially melted rocks, they are more likely to flow along crustal discontinuities than lowtemperature rocks such as the CIZ host rocks, favouring its movement along orogenic belts and their exhumation to shallower crustal levels (Paterson 2001; Jamieson et al. 2007; 2011).

The contemporaneity and similar metamorphic grade of these non-coaxial D2 structures leads to an alternative interpretation that includes the existence of a coeval pair of boundary structures in the PVMB: to the NE, a mylonitic to ultramylonitic belt displaying apparently normal kinematics; and to 575 the SW, a mylonitic low-angle thrust structure vergent to the SW sectors. The activity of this coeval pair of structures implies extrusion tectonics of the PVMB onto the CIZ low-grade slate belt. In its central sectors, the PVMB is surrounded by the low- to very low-grade metasediments of the Valongo anticline to the NE, whereas to the SW it is bounded by the recumbent Oliveira de Azeméis - Albergaria-a-Velha Syncline, both showing vergence to the SW. The presence of near sub-horizontal foliation in some of 
the diatexites and syn-orogenic granites in the SW boundary is consistent to the proposed model and is the probable reason for the generation of the sub-horizontal nodular biotite present in the famous geological site of the Castanheira Granite (Fig. 4f; Pedras Parideiras geosite, near Arouca). The localscale strain features observed in this particular granite are an example of fractal geometry, if the entire belt is considered.

The exhumation of high-grade metamorphic complexes has been the focus of several geodynamic models, including extensional tectonics (e.g. Rey et al. 2009; Horton \& Leech 2013), late-orogenic gravitational/orogenic collapse (e.g. Martínez Catalan et al. 2007; Bento dos Santos et al. 2010; 2011c; 2015), buoyancy-driven flow (e.g. Teyssier \& Whitney 2002; Whitney et al. 2004) and channel flow (e.g. Beaumont et al. 2001; Law et al., 2006; Harris 2007; Searle 2013). Considering the data presented in this work and the integrated view on the metamorphic pattern and kinematics of the shear zones delimiting the PVMB, the most consistent geodynamic model for the PVMB is exhumation by channel flow, followed by extrusion tectonics (Fig. 11). The obtained retrogressive P-T path (Fig. 9) further constrains this process as channel flow at near isobaric cooling, followed by extrusion with isothermal decompression, as depicted by the channel flow models of Law et al. (2006) and Harris (2007). boundaries, considering it an anatectic complex confined by coeval shear zones of antithetical, but coherent kinematics within an extrusion process related to post-D1 compressive tectonics. Therefore, it includes compressive kinematics starting at the D1 events until the end of the late-D3 events, when tectonic collapse of the variscan mega-structure occurred. It is significantly different from the previously suggested models for the exhumation of anatectic domes/complexes in the CIZ (e.g.: Escuder Viruete et al. 1994; Valle Aguado et al. 2005; Fernández \& Pereira 2016) that implied the existence of extensional events within a largely compressive crustal process, such as the continental collision that formed the Iberian Variscan Massif. The geodynamic model proposed by Pereira et al. (2017a) for the exhumation of the nearby Figueira de Castelo Rodrigo - Lumbrales Anatectic Complex, consisting of a two-stage exhumation due to simple shear dominated transpression, is not incompatible with the model now proposed, as the authors concluded that different mechanisms at different periods could have existed.

There are still few geochronological constraints to the exhumation process of the PVMB, being some of the ages so far provided dubious. However, an ${ }^{40} \mathrm{Ar}^{139} \mathrm{Ar}$ age on S2 biotites from sillimanite- 
bearing schists of Serra da Freita sector provided 333.5 \pm 4.4 Ma and was interpreted as related to the early D3 phase (Acciaioli et al. 2005), whereas an ${ }^{40} \mathrm{Ar}^{139} \mathrm{Ar}$ age of $312.8 \pm 3.3 \mathrm{Ma}$ in retrogressive muscovite from Ky-St-bearing mylonitic schists can be used to constrain the late stages of D3 (Acciaioli et al. 2005). Because muscovite formation in the Ky-St-bearing mylonitic schists is a late feature associated to the exhumation, the $312.8 \mathrm{Ma}$ age must be envisaged as a minimum age for the emplacement of the PVMB onto the host rocks. Late-D3 granite intrusion of the PVMB by the Castro Daire granite at $305 \pm 6 \mathrm{Ma}$ (Rb-Sr age; Serrano Pinto, 1983) also constrain the exhumation event. In the Figueira do Castelo Rodrigo - Lumbales Anatectic Complex (Pereira et al. 2017), further to the E of the PVMB, migmatite and anatectic granite formation occurred at 319-314 Ma, whereas exhumation of the complex was mostly prevalent from 309 - $301 \mathrm{Ma}$, displaying substantial evidence for rapid tectonic exhumation (Ferreira et al. 2019; in press).

Finally, this work emphasizes the importance of the shear zones delimiting the PVMB as capable of exhuming middle and lower-crust rocks, such as the studied anatectic complex. When considered their connection with the shear zones delimiting the Figueira de Castelo Rodrigo - Lumbrales Anatectic Complex (the Juzbado-Penalva do Castelo and Huebra shear zones; Pereira et al. 2017a), a prominent anisotropic feature within the CIZ emerges. For its relevance and location, it is plausible to suggest that these anatectic complexes are emplaced in the most likely boundary between the Neoproterozoic - Cambrian sedimentary basins of the Douro Group, to the North, and the Beiras Group, to the South. Further geological, geochronological and isotopic studies must be performed to confirm this hypothesis.

\section{CONCLUSIONS}

The PVMB, a Variscan anatectic complex, is found to be inserted within the autochthonous sequences of the CIZ, bounded by two coeval shear zones that display apparent antithetical kinematics. The PVMB is essentially composed of migmatites in its anatectic core formed at $\mathrm{T}>800{ }^{\circ} \mathrm{C}$, but also displays staurolite-bearing schists in its borders formed at $\mathrm{T}=635^{\circ} \mathrm{C}$ and $\mathrm{P}=5.7 \mathrm{kbar}$. These unmigmatized (but still high-grade) sequences are separated from the low-grade autochthonous sequences of the CIZ by the crustal-scale shear zones delimiting the PVMB, displaying a minimum $200{ }^{\circ} \mathrm{C}$ temperature jump between the PVMB and the CIZ host rocks. Because the two shear zones bordering the PVMB are associated to the exhumation of the anatectic complex and display all the same tectono-metamorphic 
features, they must be coeval, implying that these antithetical structures exhumed the PVMB by channel flow and extrusion tectonics.

This is a new and more coherent way of interpreting the presence of anatectic complexes within the CIZ. Acquisition of new field, petrological, geochemical and geochronological data should be performed to better precise the timing and conditions of the tectonometamorphic events responsible for the formation, evolution and exhumation of this anatectic complex and to present a consistent geodynamic model for the CIZ within the framework of the Iberian Variscan Massif.

\section{Acknowledgements}

This work is a contribution to LNEG's institutional Project PETROGEO that supported field work, data sampling, analytical work and the corresponding author with a previous post-doc grant. FCT Pest programme (Pest-OE/CTE/UI0263/2011) also provided financial support for the fieldwork. The authors are grateful to Rogério Raposo, Cyntia Mourão and Pedro Rodrigues for long-term logistic support and to UTE - PLANAGEO for supporting J.F. Rodrigues and T. Bento dos Santos during the preparation of the article. This publication was supported by FCT through Project UID/GEO/50019/2013 and Project UIDB/50019/2020 - IDL. The authors are grateful to the Editor in Chief Prof. Wolf-Christian Dullo, the Editor Prof. Ingo Braun, and three anonymous reviewers for providing very helpful and insightful reviews with many comments and suggestions, therefore, improving our work.

\section{References}

Acciaioli, M.H., Santos, J.F. \& Munhá, J. 2005. Ar-Ar dates for two different stages of the Variscan D3 recorded in metapelites of Serra da Freita (North-Central Portugal). Geophysical Research Abstracts, 7, 10076.

Amaro, P., Pereira, A.R., Pereira, M., Teixeira, M., Bento dos Santos, T., Mata, J. \& Ferreira, N. 2016. Estudo petrográfico, mineralógico e geotermobarométrico preliminar do Complexo Anatéctico da Serra da Estrela. Abstracts of the VI Congresso Jovens Investigadores em Geociências - LEG 2016, Estremoz, 71-75.

Anenburg, M. \& Katzir, Y. 2014. Muscovite dehydration melting in Si-rich metapelites: microstructural evidence from trondhjemitic migmatites, Roded, Southern Israel. Mineralogy and Petrology, 108 (1): 137-152.

Aranovich, L.Y., Makhluf, A.R., Manning, C.E. \& Newton, R.C. 2014. Dehydration melting and the relationship between granites and granulites. Precambrian Research, 253, 26-37.

Areias, M., Ribeiro, M.A. \& Dória, A. 2013. Trace Element Composition in a Migmatite-Granite Complex (NW Portugal): Protolith and Melting Process Constraints. Mineralogical Magazine, 77 (5): 611-611.

Atherton, M.P., Atkin, B.P. \& Naggar, M.H. 1974. Kyanite in the Hercynian metamorphic rocks of the OportoViseu belt, North Portugal. Geologie in Mijnbouw, 53, 189-192. 
Azevedo, M.R. \& Valle Aguado, B. 2013. Origem e Instalação de Granitóides Variscos na Zona Centro-Ibérica. In: R. Dias, A. Araújo, P. Terrinha \& J. Kullberg (eds.) Geologia de Portugal. Vol. I: Geologia Prémesozóica de Portugal. Escolar Editora, Lisboa, 377-401.

Beaumont, C., Jamieson, R.A., Nguyen, M.H. \& Lee, B. 2001. Himalayan tectonics explained by extrusion of a low viscosity crustal channel coupled to focused surface denudation. Nature, 414, 738-742.

Bento dos Santos, T. 2010. Metamorfismo. In: Ferreira, N., Godinho, M., Neves, L., Pereira, A., Sequeira, A., Castro, P., Bento dos Santos, T. (Eds.) Carta Geológica de Portugal na escala de 1/50.000, Notícia Explicativa da Folha 17-A - Viseu. Laboratório de Geologia e Minas, Laboratório Nacional de Energia e Geologia, Lisboa, 34-36.

Bento dos Santos, T., Munhá, J.M.U., Tassinari, C.C.G., Fonseca, P.E. \& Dias Neto, C.M. 2010. Thermochronology of central Ribeira Fold Belt, SE Brazil: Petrological and geochronological evidence for high-temperature maintenance during Western Gondwana amalgamation. Precambrian Research, 180 (34), 285-298.

Bento dos Santos, T., Munhá, J.M.U., Tassinari, C.C.G. \& Fonseca, P.E. 2011a. The link between partial melting, granitization and granulite development in central Ribeira Fold Belt, SE Brazil: new evidence from elemental and Sr-Nd isotopic geochemistry. Journal of South American Earth Sciences, 31 (2-3), 262-278.

Bento dos Santos, T., Munhá, J.M.U., Tassinari, C.C.G., Fonseca, P.E. \& Dias Neto, C.M. 2011b. Metamorphic P-T evolution of granulites in central Ribeira Fold Belt, SE Brazil. Geosciences Journal, 15 (1), 27-51.

Bento dos Santos, T., Munhá, J.M.U., Tassinari, C.C.G., Noronha, F., Guedes, A., Fonseca, P.E., Dias Neto, C.M. \& Dória, A. 2011c. P-T-Fluid evolution and graphite deposition during retrograde metamorphism in Ribeira Fold Belt, SE Brazil: oxygen fugacity, fluid inclusions and C-O-H isotopic evidence. Journal of South American Earth Sciences, 31 (1), 93-109.

Bento dos Santos, T., Tassinari, C.C.G. \& Fonseca, P.E. 2014. Garnet-biotite diffusion mechanisms in granulites from Ribeira Fold Belt (SE Brazil): Understanding and constraining petrological cooling rates in complex high-grade orogenic belts. Journal of South American Earth Sciences, 56, 128-138.

Bento dos Santos, T., Tassinari, C.C.G. \& Fonseca, P.E. 2015. Diachronic collision, slab break-off and long-term high thermal flux in the Brasiliano - Pan-African orogeny: Implications for the geodynamic evolution of the Mantiqueira Province. Precambrian Research, 260, 1-22.

Cândido de Medeiros, A., Simões de Carvalho, O., Vieira Dias, H., Andrade Moreira, P., Lima, J., Sousa Soeiro, M.D. \& Fernandes, I.A. 1963. Carta Geológica de Portugal à escala 1/50.000, Folha 13-B - Castelo de Paiva. Serviços Geológicos de Portugal, Direção Geral de Minas e Serviços Geológicos, Lisboa.

Carrington da Costa, J., Teixeira, C., Cândido de Medeiros, A., Matos, M., Carreira de Deus, P., Oliveira, J., Rodrigues, L. \& Gonçalves Rodrigues, A. 1957. Carta Geológica de Portugal à escala 1/50.000, Folha 9C - Porto. Serviços Geológicos de Portugal, Direção Geral de Minas e Serviços Geológicos, Lisboa.

Castro, P., Tassinari, C., Pereira, E., Dias, G. \& Leterrier, J. 2003. Geocronologia do Complexo Metamórfico de Miranda do Douro (NE de Trás-os-Montes, Portugal), Implicações geodinâmicas. Ciências da Terra, V, D29-D30.

Clemens, J. \& Vielzeuf, D. 1987. Constraints on melting and magma production in the crust. Earth and Planetary Science Letters, 86, 287-306. 
Cotrim, B., Bento dos Santos, T., Mata, J., Benoit, M. \& Jesus, A.P., in press. Lower Paleozoic rifting event in Central Iberian Zone (central-north Portugal): evidence from elemental and isotopic geochemistry of metabasic rocks. Geochemistry.

Dallmeyer, R.D., Martínez Catálan, J.R., Arenas, R., Gil Ibarguchi, J.I., Gutiérrez-Alonso, G., Farias, P., Aller, J. \& Bastida, F. 1997. Diachronous variscan tectonothermal activity in the NW Iberian Massif: evidence from ${ }^{40} \mathrm{Ar} /{ }^{39} \mathrm{Ar}$ dating of regional fabrics. Tectonophysics, 277, 307-337.

Dias, R. \& Ribeiro, A. 1994. Constriction in a transpressive regime: an example in the Iberian branch of the IberoArmorican Arc. Journal of Structural Geology, 16 (11), 1545-1554.

Dias, R. \& Ribeiro, A. 2013. O Varisco do sector norte de Portugal. In: R. Dias, A. Araújo, P. Terrinha, J.C. Kullberg (eds) Geologia de Portugal, Vol. I: Geologia Pré-mesozóica de Portugal. Escolar Editora, Lisboa, 59-71.

Dias, R., Ribeiro, A., Coke, C., Pereira, E., Rodrigues, J., Castro, P., Moreira, N. \& Rebelo, J. 2013. Evolução estrutural dos sectores setentrionais do autóctone da Zona Centro-Ibérica. In: Dias, R., Araújo, A., Terrinha, P. \& Kullberg, J.C. (eds) Geologia de Portugal, Vol. I: Geologia Pré-mesozóica de Portugal. Escolar Editora, Lisboa, 73-147.

Díez Balda, M., Martínez Catalán, J. \& Ayarza Arribas, P. 1995. Syn-collisional extensional collapse parallel to the orogenic trend in a domain of steep tectonics: the Salamanca Detachment Zone (Central Iberian Zone, Spain). Journal of Structural Geology, 17, 163-182.

Escuder Viruete, J., Arenas, R. \& Martinez Catalan, J. 1994. Tectonothermal evolution associated with Variscan crustal extension in the Tormes Gneiss Dome (NW Salamanca, Iberian Massif, Spain). Tectonophysics, 238, $117-138$.

Esteves, A.F.M. 2006. As rochas metamórficas da região de Viseu. Unpublished MSc Thesis. Universidade de Aveiro, 124p.

Farinha Ramos, J.M., Schermerhorn, L.S.G., Sluijk, D., Avila Martins, J. \& Peinador Fernandes, A., 1977. Carta Geológica de Portugal à escala 1/50.000, Folha 14-C-Castro Daire. Serviços Geológicos, Direção Geral de Minas e Serviços Geológicos, Lisboa.

Fernández, R.D. \& Pereira, M.F. 2016. Extensional orogenic collapse captured by strike-slip tectonics: Constraints fromstructural geology and $\mathrm{U}-\mathrm{Pb}$ geochronology of the Pinhel shear zone (Variscan orogen, Iberian Massif). Tectonophysics, 691 (B), 290-310.

Ferreira, J.A. 2013a. Caracterização do granito do Pedregal. Condicionantes da sua aplicação. Unpublished MSc Thesis, Universidade do Porto, 155p.

Ferreira, J.A., Ribeiro, M.A. \& Martins, H.C.B. 2014. The Pedregal granite: petrographic and geochemical characterization of a peculiar granitoid. Estudios Geológicos, 70 (2): e019.

Ferreira, J.A., Martins, H.C.B., Santos, J.F. \& Ribeiro, M.A. 2015. Características isotópicas (Sr-Nd) do Granito do Pedregal e rochas migmatíticas associadas. Comunicações Geológicas, 102, 147-151.

Ferreira, J.A., Pereira, I., Bento dos Santos, T., Mata, J., Dias, R., Ribeiro, M.A.\& Martins, H.C.B. 2016. Migmatitos da Zona Centro-Ibérica: comparação entre o complexo migmatítico do Pedregal e o Complexo Anatéctico de Figueira de Castelo Rodrigo - Lumbrales. Abstracts of the VI Congresso Jovens Investigadores em Geociências - LEG 2016, Estremoz, 49-52. 
Ferreira, J.A., Bento dos Santos, T., Pereira, I. \& Mata, J., 2019. Tectonically assisted exhumation and cooling of Variscan granites in an anatectic complex of the Central Iberian Zone, Portugal: constraints from LA- ICP- MS zircon and apatite U-Pb ages. International Journal of Earth Sciences, 108, 2153-2175.

Ferreira, J.A., Mata, J., Bento dos Santos, T. \& Pereira, I., 2020. The role of melting on the geochemical evolution and isotopic variability of an anatectic complex in the Iberian Variscides. Lithos, 378-379, 105769.

Ferreira, J.A., Pereira, I., Bento dos Santos, T. \& Mata, J., in press. U-Pb age constraints on the source, cooling and exhumation of a Variscan middle crust migmatite complex from the Central Iberian Zone: insights into the Variscan metamorphic evolution and Ediacaran paleogeographic implications. Tectonophysics.

Ferreira, N., Castro, P., Godinho, M., Neves, L., Pereira, A., Ferreira Pinto, A., Simões, L., Silva, F.G., Aguado, B., Azevedo, M.R., Esteves, F., Sequeira, A. \& Bento dos Santos, T. 2009. Carta Geológica de Portugal à escala 1/50.000, Folha 17A - Viseu. Laboratório de Geologia e Minas, Laboratório Nacional de Energia e Geologia, Lisboa.

Ferreira, N., Godinho, M., Neves, L., Pereira, A., Sequeira, A., Castro, P. \& Bento dos Santos, T. 2010. Carta Geológica de Portugal na escala de 1/50 000, Notícia Explicativa da Folha 17A - Viseu. Laboratório de Geologia e Minas, Laboratório Nacional de Energia e Geologia, Lisboa, 66.

Ferreira N. \& Silva A. 1999. Carta Geológica Simplificada do Parque Natural da Serra da Estrela, escala 1/75 000. Instituto Geológico Mineiro e Instituto da Conservação da Natureza.

Ferreira, P.M.A.F. 2013b. Aspetos cartográficos, estruturais e metamórficos da Faixa Metamórfica Porto-Viseu: transversal na região entre a foz do rio Sousa e a barragem Crestuma-Lever. Unpublished MSc Thesis, Universidade do Porto, 116.

Fyfe, W.S. 1973. The granulite facies, partial melting and the Archaean crust. Philosophical Transactions of the Royal Society of London, A273, 457-461.

Gomes, M.E.P., Martins, L.M.O., Neves, L.J.P.F. \& Pereira, A.J.S.C. 2013. Natural radiation and geochemical data for rocks and soils, in the North International Douro Cliffs (NE Portugal). Journal of Geochemical Exploration, 130, 60-64.

Gomes, M.E.P., Teixeira, R.J.S., Neiva, A.M.R. \& Corfu, F. 2011. Geochemistry and geochronology of granitic rocks from the Bemposta-Picote area (Northeast Portugal). Abstracts of the Seventh Hutton Symposium on Granites and Related Rocks, Avila (Spain), 62-63.

Gonçalves, L.S.M., Araújo, J.R.F., Fonseca, E.C., Serrano Pinto, M.C. \& Ferreira Pinto, A.F. 1990. Carta Geológica de Portugal à escala 1/50.000, Folha 17-B - Fornos de Algodres. Serviços Geológicos de Portugal, Direção Geral de Minas e Serviços Geológicos, Lisboa.

Gutiérrez-Marco, J.C., San Jose, M. \& Pieren, A. 1990. Central Iberian Zone, Authochtonous Sequences: PostCambrian Palaeozoic Stratigraphy. In: R.D. Dallmeyer \& Martínez García (eds.) Pre-Mesozoic Geology of Iberia. Springer Verlag, 160-169.

Harris, N. 2007. Channel flow and the Himalayan-Tibetan orogen: a critical review. Journal of the Geological Society, 164 (3), 511-523.

Hodges, K.V. \& Crowley, P.D. 1985. Error estimation and empirical geothermobarometry for pelitic systems. American Mineralogist, 70, 702-709.

Holland, T.J.B. \& Powell, R. 1998. An internally-consistent thermodynamic dataset for phases of petrological interest. Journal of Metamorphic Geology, 16, 309-344. 
Horton, F. \& Leech, M.L. 2013. Age and origin of granites in the Karakoram shear zone and Greater Himalaya Sequence, NW India. Lithosphere, doi: 10.1130/L213.1.

Iglesias, M. \& Ribeiro, A. 1981. La zone de cisaillement ductile Juzbado (Salamanca) - Penalva do Castelo (Viseu): un linéament réactivé pendant l'orogénèse hercynienne? Comunicações dos Serviços Geológicos de Portugal, 67 (1), 89-93.

Jamieson, R.A., Beaumont, C., Nguyen, M.H. \& Culshaw, N.G. 2007. Synconvergent ductile flow in variablestrength continental crust: Numerical models with application to the western Grenville orogen. Tectonics, 26, TC5005.

Jamieson, R.A., Unsworth, M.J., Harris, N.B.W., Rosenberg, C.L. \& Schulmann, K. 2011. Crustal Melting and the Flow of Mountains. Elements, 7, 253-260.

Jesus, A.P., Mateus, A., Munhá, J.M., Tassinari, C.C.G., Bento dos Santos, T. \& Benoit, M. 2016. Evidence for underplating in the genesis of the Variscan synorogenic Beja Layered Gabbroic Sequence (Portugal) and related mesocratic rocks. Tectonophysics, $\mathbf{6 8 3}, 148-171$.

Julivert, M., Fontboté, J.M., Ribeiro, A. \& Conde, L.N. 1972. Mapa Tectónico de la Península Ibérica y Baleares. Instituto Geológico y Minero de España.

Law, R.D., Searle, M.P., Godin, L., 2006. Channel Flow, Ductile Extrusion and Exhumation in Continental Collision Zones. Geological Society of London Special Publications, 268, 638.

LNEG, 2010. Carta Geológica de Portugal à escala 1: 1.000.000. Laboratório Nacional de Energia e Geologia, Lisboa, Portugal.

Martínez Catalán, J.R., Arenas, R., Díaz García, F., Gómez-Barreiro, J., González Cuadra, P., Abati, J., Castiñeiras, P., Fernández-Suárez, J., Sánchez Martínez, S., Andonaegui, P., Gónzalez Clavijo, E., Díez Montes, A., Rubio Pascual, F.J. \& Valle Aguado, B. 2007. Space and time in the tectonic evolution of the northwestern Iberian Massif. Implications for the comprehension of the Variscan belt. In: Hatcher, R.D.Jr., Carlson, M.P., McBride, J.H. \& Martínez Catalán, J.R. (eds.) 4-D framework of continental crust. Geological Society of America memoir, 200, 403-423.

Medeiros, A., Pereira, E., Moreira, A., Silva, N., Lima, J., Moreira, P., Matos, M. \& Monteiro, J. 1981. Carta Geológica de Portugal à escala 1/50.000, Folha 9-D - Penafiel. Serviços Geológicos de Portugal, Direção Geral de Minas e Serviços Geológicos, Lisboa.

Milord, I., Sawyer, E.W. \& Brown, M. 2001. Formation of diatexite migmatite and granite magma during anatexis of semi-pelitic metasedimentary rocks: an example from St. Malo, France. Journal of Petrology, 42 (3), 487-505.

820 Noronha, F., Ramos, J.M., Rebelo, J.A., Ribeiro, A. \& Ribeiro, M.L. 1979. Éssai de corrélation des phases de déformation hercynienne dans le Nord-Ouest Péninsulaire. Boletim da Sociedade Geológica de Portugal, 21, 227-237.

Ntarmouchant, A., Smaili, H., Bento dos Santos, T., Dahire, M., Sabri, K., Ribeiro, M.L., Driouch, Y., Santos, R. \& Calvo, R. 2016. New evidence of effusive and explosive volcanism in the Lower Carboniferous formations of the Moroccan Central Hercynian Massif: geochemical data and geodynamic significance. Journal of African Earth Sciences, 115, 218-233. 
Oliveira, J.T., Pereira, E., Piçarra, J.M., Young, T. \& Romano, M. 1992. O Paleozóico Inferior de Portugal: síntese da estratigrafia e da evolução paleogeográfica. In: J.C. Gutiérrez-Marco \& I. Rábano (Eds.) Paleozóico Inferior de Ibero-América. Universidade de Estremadura, 505-521.

Paterson, M.S. 2001. A granular flow theory for the deformation of partially melted rock. Tectonophysics, $\mathbf{3 3 5}$, 51-61.

Patiño Douce, A.E. \& Beard, J.S. 1995. Dehydration-melting of Biotite Gneiss and Quartz Amphibolite from 3 to 15 kbar. Journal of Petrology, 36 (3), 707-738.

Pereira, A.R., Pereira, M., Teixeira, M., Amaro, P., Bento dos Santos, T. \& Mata, J. 2017b. Migmatitos: características petrológicas e geoquímicas, formação e evolução. Geonovas, 30, 79-86.

Pereira, E., Moreira, A., Gonçalves, S., Rodrigues, J. \& Silva, A.F. 2005. Carta Geológica de Portugal à escala 1/50.000, Folha 13D - Oliveira de Azeméis. Instituto Nacional de Engenharia, Tecnologia e Inovação, Lisboa.

Pereira, I., Dias, R., Bento dos Santos, T. \& Mata, J. 2017a. Exhumation of a migmatite complex along a transpressive shear zone: inferences from the Variscan Juzbado-Penalva do Castelo Shear Zone (Central Iberian Zone). Journal of the Geological Society, 174 (6), 1004-1018.

Pereira, I., Storey, C.D., Strachan, R.A., Bento dos Santos, T. \& Darling, J.R., 2020. Detrital rutile ages can deduce the tectonic setting of sedimentary basins. Earth and Planetary Science Letters, 537, 116193.

Ramsay, J.G. \& Huber, M.I. 1987. The techniques of modern structural geology-Volume 2: Folds and fractures. Academic Press, London, 700p.

Reavy, R.J., Stephens, W.E., Fallick, A.E., Halliday, A.N. \& Godinho, M.M. 1991. Geochemical and isotopic constraints on petrogenesis: The Serra da Freita pluton, a typical granite body from the Portuguese Hercynian collision belt. Geological Society of America Bulletin, 103, 392-401.

Rey, P.F., Teyssier, C. \& Whitney, D.L. 2009. The Role of Partial Melting and Extensional Strain Rates in the Development of Metamorphic Core Complexes. In: Chardon, D., Rey, P., Teyssier, C. \& Whitney, D.L. (eds.) Hot Orogen. Tectonophysics, 477, 135-144.

Ribeiro, A. 1974. Conribuition à l'étude tectonique de Trás-os-Montes Oriental. Memórias dos Serviços Geológicos de Portugal, 24, 168.

Ribeiro, A. 2013. A Evolução Geodinâmica de Portugal; os ciclos ante-mesozóicos. In: Dias, R., Araújo, A., Terrinha, P., Kullberg, J. C. (eds.) Geologia de Portugal no contexto da Ibéria. Univ. Évora. Évora, 15-57.

Ribeiro, A., Quesada, C. \& Dallmeyer, R.D. 1990. Geodynamic evolution of the Iberian Massif. In: Dallmeyer, R.D., \& Martínez-Garcia, E. (eds.) Pre-Mesozoic Geology of Iberia, Springer-Verlag, Berlin, 397-410.

Ribeiro, A., Munhá, J., Mateus, A., Fonseca, P., Pereira, E., Noronha, F., Romão, J., Rodrigues, J., Castro, P., Meireles, C. \& Ferreira, N. 2009. Mechanics of thick-skinned Variscan overprinting of Cadomian basement (Iberian Variscides). Comptes Rendu Geoscience, 341, 127-139.

Ribeiro, M.A., Sant'Ovaia, H., Martins, H.C.B., Dória, A., Areias, M. \& Ferreira, J. 2014. Evolução tectonometamórfica, migmatização e magmatismo sin-tectónico na região do Porto (NW Portugal). Comunicações Geológicas, 101 (I), 297-300.

Ribeiro, M.A., Areias, M., Ferreira, J., Martins, H. \& Sant'Ovaia, H. 2015. Geological and petrological constraints on the variscan evolution of the NW area of Porto-Viseu Belt. Géologie de la France, 1, 119-120. 
Ribeiro, M.L., Reche, J., López-Carmona, A., Aguilar-Gil, C., Bento dos Santos, T., Chichorro, M., Dias da Silva, I., Díez-Montes, A., González-Clavijo, E., Gutiérrez-Alonso, G., Leal, N., Liesa, M., Martínez, J.F., Mateus, A., Mendes, M.H., Moita, P., Pedro, J., Quesada, C., Santos, J.F., Solá, A.R. \& Valverde-Vaquero, P., 2019. 12. Variscan Metamorphism. In: Quesada, C., Oliveira, J.T. (Eds.) The Geology of Iberia: A Geodynamic Approach, 2 - The Variscan Cycle. Regional Geology Reviews, Springer, Heidelberg, 431495.

Sá, A.A., Meireles, C., Correia, P., Piçarra, J., Castro, P., Rocha, D., Ferreira, P. \& Flores, D. 2014. A sequência paleozóica da região de Valongo - Arouca (N de Portugal). Livro guia da Saída de Campo $n^{o} 5$. IX Congresso Nacional de Geologia - II Congresso de Geologia dos Países de Língua Portuguesa, 75-94.

875 Sawyer, E.W. 2008. Atlas of Migmatites. National Research Council of Canada, 371p.

Sawyer, E.W., Cesare, B. \& Brown, M. 2011. When the continental crust melts. Elements, 7, 220-234.

Schulmann, K., Schaltegger, U., Jezek, J., Thompson, A.B. \& Edel, J. 2002. Rapid burial and exhumation during orogeny: Thickening and synconvergent exhumation of thermally weakened and thinned crust (variscan orogeny in Western Europe). American Journal of Science, 302, 856-879.

Searle, M. 2013. Crustal melting, ductile flow, and deformation in mountain belts: Cause and effect relationships. Lithosphere, 8 (6), 547-554.

Serrano Pinto, M., 1983. Geochronology of Portuguese granitoids: a contribution. Studia Geologica Salmanticensia, XVIII, 277-306.

Silva, M.A. 2014. Petrogenesis of a variscan migmatite complex (NW Portugal): petrography, geochemistry and fluids. Unpublished PhD thesis, Universidade do Porto, Porto, 436p.

Soen, O.Y. 1958. The geology, petrology and ore deposits of the Vizeu region, northern Portugal. Comunicações dos Serviços Geológicos de Portugal, 41, 5-199.

Soen, O.Y. 1970. Granite intrusion, folding and metamorphism in central northern Portugal. Boletín Geológico y Minero, LXXXI-II-III: 271-289.

Sousa, B.R.P.L. 2013. As Rochas Metamórficas da Região de Sátão (Zona Centro-Ibérica). Unpublished MSc thesis, University of Aveiro, 58.

Sousa, M.B. \& Sequeira, A.J.D. 1993. O limite Precâmbrico-Câmbrico na Zona Centro Ibérica em Portugal. Abstracts of the XII Reunião de Geologia do Oeste Peninsular, Évora, 1, 17-28.

Spear, F. \& Florence, F. 1992. Thermobarometry in granulites: Pitfalls and new approach. Precambrian Research, 55, 209-241.

Spear, F.S., Kohn, M. \& Cheney, J. 1999. P-T paths from anatectic pelites. Contributions to Mineralogy and Petrology, 134, 17-32.

Stevens, G., Clemens, J.D. \& Droop, G.T.R. 1997. Melt production during granulite-facies anatexis: experimental data from 'primitive' metasedimentary protoliths. Contributions to Mineralogy and Petrology, 128, 352370.

Talavera, C., Montero, P., Martínez Poyatos, D. \& Williams, I.S. 2012. Ediacaran to Lower Ordovician age for rocks ascribed to the Schist-Graywacke Complex (Iberian Massif, Spain): Evidence from detrital zircon SHRIMP U-Pb geochronology. Gondwana Research, 22, 928-942. 
Teixeira, C., Correia Perdigão, J., Oliveira, J. \& Nery, F. 1962. Carta Geológica de Portugal à escala 1/50.000,

Folha 13-A - Espinho. Serviços Geológicos de Portugal, Direção Geral de Minas e Serviços Geológicos, Lisboa.

Teixeira, C., Cândido de Medeiros, A., Matos, M., Carreira de Deus, P., Oliveira, J., Rodrigues, A. \& Lima, J. 1965. Carta Geológica de Portugal à escala 1/50.000, Folha 9-A - Póvoa de Varzim. Serviços Geológicos de Portugal, Direção Geral de Minas e Serviços Geológicos, Lisboa.

910 Teyssier, C. \& Whitney, D.L. 2002. Gneiss domes and orogeny. Geology, 30, 1139-1142.

Valle Aguado, B., Arenas, R. \& Martínez Catalán, J.R. 1993. Evolución metamórfica hercínica en la región de la Serra de Arada (Norte de Portugal). Comunicações do Instituto Geológico e Mineiro, 79, 41-61.

Valle Aguado, B. \& Azevedo, M.R. 2006. Trajectórias PTt na cintura metamórfica de Porto Viseu: implicações no magmatismo granítico. Abstacts of the VII Congresso Nacional de Geologia, Estremoz, 3, 1215-1218.

Valle Aguado, B., Azevedo, M.R., Nolan, J., Medina, J., Costa, M.M., Corfu, F. \& Martínez Catalán, J.R. 2017. Granite emplacement at the termination of a major Variscan transcurrent shear zone: The late collisional Viseu batholith. Journal of Structural Geology, 98, 15-37.

Valle Aguado, B., Azevedo, M.R., Santos, J.F. \& Nolan, J. 2010. O complexo migmatítico de Mundão (Viseu, norte de Portugal). VIII Congresso Nacional de Geologia. e-Terra, 16 (9), 4.

Valle Aguado, B., Azevedo, M.R., Schaltegger, U., Martínez Catalán, J. \& Nolan, J. 2005. U-Pb zircon and monazite geochronology of Variscan magmatism related to syn-convergence extension in Central Northern Portugal. Lithos, 82, 169-184.

Vielzeuf, D. \& Holloway, J. 1988. Experimental determination of the fluid-absent melting relations in the pelitic system. Contributions to Mineralogy and Petrology, 98, 257-276.

925 Whitney, D.L. \& Evans, B.W. 2010. Abbreviations for names of rock-forming minerals. American Mineralogist, 95, 185-187.

Whitney, D.L., Teyssier, C. \& Fayon, A.K. 2004. Isothermal decompression, partial melting and exhumation of deep continental crust. Geological Society London Special Publications, 227 (1), 313-326.

Wimmenauer, W. \& Brihni, I. 2007. 6. Migmatites and related rocks. IUGS Subcommission on the Systematics of Metamorphic Rocks - http://www.bgs.ac.uk/SCMR/docs/papers/paper_6.pdf 


\section{Captions}

Figure 1 - Geological setting of the Porto - Viseu Metamorphic Belt (PVMB) within the CentralIberian Zone ( $\mathrm{CIZ}$ ) of the Iberian Variscan Massif: a) The major geological domains of the Iberian Variscan Massif; b) Location of the PVMB and of the most important shear zones of the $\mathrm{CIZ}$ in the vicinities (other abbreviations are as presented in the text); c) Geological map of the PVMB and surrounding domains. For simplification purposes (due to the scale of the map), staurolitebearing schists in the map include both staurolite and sillimanite zones, and diatexites also include small anatectic granites. Location of the selected samples for geothermobarometric studies is also shown.

Figure 2 - Stereographic plots and rose diagrams for the mesoscopic structures in the studied sectors (A: Porto sector; B: Foz do Sousa sector; C: Serra da Freita sector; D: Viseu-Penalva do Castelo sector; E: Oliveira de Azeméis sector) to show the major structural features in the PVMB. For every purpose, stereograms (equal area lower hemisphere plots) are as follows: 1 ) density plots of poles of S2 foliation planes; 2 ) rose diagrams for maximum dip direction of S2 planes; 3 ) density plots of mineral lineation measurements. Rose diagrams are shown for comparison between dip directions of S2 and mineral lineations within S2. The entire set of presented structural data was obtained by this work ( $40 \%)$ and compilation of previously presented data in: Teixeira et al. (1962; 1965), Carrington da Costa et al. (1957), Medeiros et al. (1981) Cândido de Medeiros et al. (1963), Pereira et al. (2006), Farinha Ramos et al. (1977), Ferreira et al. (2009), Gonçalves et al. (1990), Esteves (2006), Ferreira (2013), Sousa (2013) and Valle Aguado et al. (2005). Also shown is location of the cross section (X-Y) of Fig. 3 and location of the detailed map in Fig. 10.

Figure 3 - SW-NE (X-Y) cross section of the PVMB's structural and metamorphic main features. Location is shown in Fig. 2. Additional data is presented in the Structural Analysis section, whereas interpretation is made in the Discussion section. However, it is possible to verify that both the structural features (discussed in the text) and the metamorphic pattern of the PVMB implies seemingly normal kinematics (i.e.: top to the NE) in the NE portion of the cross section, whereas in the SW portion reverse kinematics (i.e.: top to the SW) is present.

Figure 4 - Details of the most important structural features presented by the PVMB's rocks: a) staurolite/andalusite porphyroclasts showing an anastomosed fabric due to mylonitization; b-c) 
porphyroclastic systems developed from staurolite crystals in the NE boundary sector showing top to the NE sense of movement; d) staurolite-bearing mylonitic schist displaying several features of deformation on the staurolite porphyroclasts; e) S/C structures in the SW boundary (Oliveira de Azeméis sector) showing top to the SW sense of movement; f) famous Castanheira Granite (Pedra Parideira geological site), located near the SW boundary of the PVMB, with nodular biotite. The deflection (assimetry) of the biotite nodules, in a plane along its elongation and normal to the exposure, allows to interpret a top to the SW movement.

Figure 5 - Details of the most common lithologies within the PVMB: a-b) staurolite-bearing mylonitic schists from Mundão (Viseu-Penalva do Castelo sector) (b) and Foz do Sousa (a); c) metatexites showing ptygmatic folding in Serra da Freita; d) Cavernães diatexite (Viseu-Penalva do Castelo sector) displaying late biotite recrystallization after D3 deformation caused from the Juzbado - Penalva do Castelo Shear Zone in the SE extremity of the PVMB.

Figure 6-Details of the most important petrographic and textural aspects of the studied rocks: a) diatexites with hercynite from Pedregal (Porto sector); b) metasedimentary enclaves (metatexitic residues) in diatexites in Pedregal; c) augen texture in the staurolite-bearing mylonitic schists of Foz do Sousa; d) centimetric staurolite porphyroclasts in the Serra da Freita mylonites; e) M2 andalusite (chiastolite) pseudomorphs replacing M1 staurolite porphyroclasts; f) staurolite-bearing mylonitic schists displaying millimetric-thick veinlets of migmatitic liquid formed by late decompressive anatexis.

Figure 7 - Petrographic details of the most important textural aspects of the studied rocks: a) garnet-staurolite-bearing schists of Foz do Sousa sector. It is possible to observe that S2 is occasionally folded by D3 (as in Ferreira, 2013b); b) transition zone between staurolite-bearing schists and incipient metatexites in the Serra da Freita sector. K-feldspar porphyroblasts $(>1 \mathrm{~cm})$ with $\mathrm{St}+\mathrm{Bt} \pm \mathrm{Ms}$ inclusions, evidencing the prograde reactions occurring during migmatite formation; c) typical metatexite from the Serra da Freita sector showing veinlets of neosome. Paleosome still shows small staurolite crystals; d) typical incipient metatexite from ViseuPenalva do Castelo sector showing pockets of liquid surrounded by Ms-rich paleosome; e) transition zone between metatexites and diatexites in Viseu-Penalva do Castelo sector. It is possible to observe abundant sillimanite in the melt portions, as well as an overall loss in anisotropy, which is typical of diatexites; f) calc-silicate rock interlayered within the metatexites; g) the previously labelled Cavernães Granite, now interpreted as being a diatexite (Viseu-Penalva do Castelo sector); h) typical features of a diatexite from the Oliveira de Azeméis sector. 
Figure 8 - Petrographic details of the garnet-staurolite micaschist sample (P11a) from Foz do Sousa that was used for geothermobarometric estimation with THERMOCALC: a) an example of the location of some of the spots analysed by EPMA; b) backscattered image of a staurolite porphyroclast showing some internal features and inclusions. Identical procedures were performed for samples A2 and 17A.

Figure 9-Inferred P-T paths of the studied rocks within the PVMB and of the host Douro - Beiras Supergroup slate belt. D1 to D3 deformation phases, M1 peak, M2 retrogressive stage and M3 contact metamorphism, as well as some petrographic/textural features are shown and correlated with tectonometamorphic events. Dashed black arrows are the inferred P-T paths taken from field and petrographic evidence. Most important reaction curves that constrain peak P-T estimation (muscovite- and biotite-out) are also shown. Quantitative results for the metamorphic peak and retrogressive stages using THERMOCALC (Holland \& Powell 1998) are shown: TH refers to P-T estimates for sample P11a (staurolite-bearing schist), red dots are the P-T estimates for sample A2 (metatexite), whereas blue dots show P-T estimates for sample 17A (calc-silicate rock within metatexites). Bold arrow shows the thermal difference (and temperature jump) between the PVMB's rocks and the host $\mathrm{ClZ}$. Green, red and blue arrows show inferred retrogressive P-T paths.

Figure 10 - Detailed mapping (modified from Esteves 2006; Valle Aguado et al. 2010) of part of the Viseu-Penalva do Castelo sector (the Cavernães area, location shown in Fig. 2) depicting the metamorphic isograds, the PVMB's NE boundary shear zone (folded by the D3 JPCSZ) and the surrounding late- to post-D3 granites of the Viseu region. Arrows show the horizontal distance between: the biotite zone and the migmatites of the PVMB (small arrow); the chlorite zone and the migmatites of the PVMB (large arrow). Transition from low-grade metasediments to migmatites occurs always in less than $2.5 \mathrm{~km}$.

Figure 11 - Tectonic model for the exhumation of the PVMB onto the $\mathrm{CIZ}$ host rocks by channel flow and extrusion tectonics. Integration of the structural and metamorphic features found in the anatectic complex reveal a symmetric metamorphic pattern and antithetical kinematics for the shear zones delimiting the PVMB. The thick black arrows show the inferred mass transport within the belt caused by extrusion within an overall compressive (empty arrows) setting during D2. This mass transport is coherent with the observed kinematics for both boundaries of the PVMB. 
Table 1 - Representative samples of the most important analysed minerals for staurolite-bearing schist P11a.

\begin{tabular}{|c|c|c|c|c|c|c|c|c|c|c|c|c|c|c|}
\hline \multirow{2}{*}{\begin{tabular}{|c|} 
Sample \\
P11a
\end{tabular}} & \multicolumn{2}{|c|}{ Staurolite } & & \multicolumn{2}{|c|}{ Garnet } & & \multicolumn{2}{|c|}{ Plagioclase } & & \multicolumn{2}{|c|}{ Biotite } & & \multicolumn{2}{|c|}{ White Mica } \\
\hline & core & rim & & core & rim & & core & rim & & core & core & & core & core \\
\hline $\mathrm{SiO}_{2}$ & 27.56 & 27.54 & & 35.61 & 35.89 & & 65.48 & 63.81 & & 36.32 & 34.66 & & 46.96 & 45.24 \\
\hline $\mathrm{TiO}_{2}$ & 0.55 & 0.70 & & 0.02 & 0.02 & & 0.01 & 0.02 & & 1.22 & 1.56 & & 0.37 & 0.38 \\
\hline $\mathrm{Al}_{2} \mathrm{O}_{3}$ & 55.63 & 55.40 & & 21.75 & 21.65 & & 21.99 & 22.57 & & 20.39 & 20.07 & & 37.06 & 37.16 \\
\hline $\mathrm{Cr}_{2} \mathrm{O}_{3}$ & 0.07 & 0.11 & & 0.04 & 0.03 & & 0.00 & 0.00 & & 0.01 & 0.00 & & 0.05 & 0.02 \\
\hline $\mathrm{Fe}_{2} \mathrm{O}_{3}$ & 0.00 & 0.00 & & 0.00 & 0.00 & & 0.00 & 0.00 & & 0.00 & 0.00 & & 0.00 & 0.00 \\
\hline $\mathrm{FeO}$ & 13.36 & 12.70 & & 32.47 & 32.72 & & 0.09 & 0.20 & & 20.51 & 20.72 & & 0.59 & 0.61 \\
\hline $\mathrm{MnO}$ & 0.31 & 0.45 & & 5.49 & 4.35 & & 0.00 & 0.00 & & 0.07 & 0.04 & & 0.00 & 0.07 \\
\hline $\mathrm{MgO}$ & 1.55 & 1.45 & & 2.32 & 2.44 & & 0.00 & 0.00 & & 8.58 & 9.55 & & 0.34 & 0.27 \\
\hline $\mathrm{CaO}$ & 0.03 & 0.02 & & 2.01 & 2.11 & & 2.80 & 3.54 & & 0.00 & 0.04 & & 0.05 & 0.00 \\
\hline $\mathrm{Na}_{2} \mathrm{O}$ & 0.05 & 0.03 & & 0.05 & 0.06 & & 9.46 & 8.89 & & 0.19 & 0.03 & & 2.10 & 1.43 \\
\hline $\mathrm{K}_{2} \mathrm{O}$ & 0.00 & 0.03 & & 0.00 & 0.03 & & 0.07 & 0.12 & & 7.67 & 8.44 & & 7.78 & 8.93 \\
\hline Total & 99.11 & 98.43 & & 99.76 & 99.30 & & 99.90 & 99.15 & & 94.96 & 95.11 & & 95.30 & 94.11 \\
\hline Sample & Staur & olite & & Garn & & & Plagioc & clase & & Biot & tite & & White & Mica \\
\hline P11a & core & rim & & core & rim & & core & rim & & core & core & & core & core \\
\hline $\mathrm{Si}$ & 7.536 & 7.565 & & 2.883 & 2.914 & & 2.876 & 2.831 & & 2.743 & 2.640 & & 3.073 & 3.019 \\
\hline $\mathrm{Ti}$ & 0.114 & 0.145 & & 0.001 & 0.001 & & 0.000 & 0.001 & & 0.069 & 0.090 & & 0.018 & 0.019 \\
\hline $\mathrm{Al}$ & 17.932 & 17.940 & & 2.076 & 2.072 & & 1.139 & 1.181 & & 1.816 & 1.802 & & 2.859 & 2.923 \\
\hline $\mathrm{Cr}$ & 0.016 & 0.025 & & 0.003 & 0.002 & & 0.000 & 0.000 & & 0.001 & 0.000 & & 0.002 & 0.001 \\
\hline $\mathrm{Fe}^{2+}$ & 3.055 & 2.918 & & 2.038 & 2.114 & & 0.000 & 0.000 & & 1.296 & 1.287 & & 0.032 & 0.034 \\
\hline $\mathrm{Mn}$ & 0.072 & 0.104 & & 0.377 & 0.299 & & 0.003 & 0.000 & & 0.005 & 0.003 & & 0.000 & 0.004 \\
\hline $\mathrm{Mg}$ & 0.631 & 0.592 & & 0.280 & 0.295 & & 0.000 & 0.000 & & 0.966 & 1.084 & & 0.033 & 0.026 \\
\hline $\mathrm{Ca}$ & 0.008 & 0.005 & & 0.174 & 0.184 & & 0.132 & 0.168 & & 0.000 & 0.004 & & 0.004 & 0.000 \\
\hline $\mathrm{Na}$ & 0.025 & 0.016 & & 0.007 & 0.009 & & 0.806 & 0.765 & & 0.027 & 0.004 & & 0.266 & 0.185 \\
\hline K & 0.000 & 0.012 & & 0.000 & 0.003 & & 0.004 & 0.007 & & 0.739 & 0.820 & & 0.649 & 0.760 \\
\hline Total & 29.389 & 29.322 & & 7.999 & 8.000 & & 4.960 & 4.960 & & 7.662 & 7.766 & & 6.936 & 6.971 \\
\hline$X_{\text {Mst }}$ & 0.171 & 0.169 & $X_{P y}$ & 0.098 & 0.102 & $X_{A n}$ & 0.14 & 0.18 & $\mathrm{X}_{\mathrm{Phl}}$ & 0.427 & 0.457 & $\mathrm{X}_{\mathrm{Mu}}$ & 0.694 & 0.788 \\
\hline$X_{\text {Fst }}$ & 0.829 & 0.831 & $X_{\text {Gross }}$ & 0.061 & 0.064 & $X_{\mathrm{Ab}}$ & 0.86 & 0.81 & $X_{\text {Ann }}$ & 0.573 & 0.543 & $X_{\mathrm{Pg}}$ & 0.291 & 0.196 \\
\hline & & & $X_{\text {Alm }}$ & 0.710 & 0.731 & Xort & 0.00 & 0.01 & & & & $X_{\text {Cel }}$ & 0.008 & 0.009 \\
\hline & & & $X_{\text {Spss }}$ & 0.131 & 0.103 & & & & & & & $X_{\text {Fcel }}$ & 0.008 & 0.007 \\
\hline
\end{tabular}


Table 2 - Representative samples of the most important analysed minerals for migmatite A2.

\begin{tabular}{|c|c|c|c|c|c|c|c|c|c|c|c|c|c|}
\hline \multirow{2}{*}{\begin{tabular}{|c} 
Sample \\
A2
\end{tabular}} & \multicolumn{2}{|c|}{ Garnet } & & \multicolumn{2}{|c|}{ Plagioclase } & & \multicolumn{2}{|c|}{ K-feldspar } & & \multicolumn{2}{|c|}{ Biotite } & \multicolumn{2}{|c|}{ IImenite } \\
\hline & core & rim & & core & rim & & core & rim & & core & core & core & core \\
\hline $\mathrm{SiO}_{2}$ & 37.21 & 37.20 & & 65.71 & 68.92 & & 65.39 & 65.78 & & 35.27 & 36.08 & 0.01 & 0.01 \\
\hline $\mathrm{TiO}_{2}$ & 0.13 & 0.04 & & 0.00 & 0.02 & & 0.00 & 0.00 & & 3.76 & 3.30 & 53.75 & 53.29 \\
\hline $\mathrm{Al}_{2} \mathrm{O}_{3}$ & 21.46 & 21.48 & & 21.82 & 19.99 & & 18.76 & 18.75 & & 18.63 & 18.69 & 0.00 & 0.00 \\
\hline $\mathrm{Cr}_{2} \mathrm{O}_{3}$ & 0.15 & 0.17 & & 0.00 & 0.00 & & 0.00 & 0.00 & & 0.28 & 0.12 & 0.08 & 0.02 \\
\hline $\mathrm{Fe}_{2} \mathrm{O}_{3}$ & 0.00 & 0.00 & & 0.00 & 0.00 & & 0.00 & 0.00 & & 0.00 & 0.00 & 0.00 & 0.00 \\
\hline $\mathrm{FeO}$ & 35.13 & 35.43 & & 0.30 & 0.07 & & 0.01 & 0.01 & & 21.58 & 20.60 & 44.67 & 44.95 \\
\hline $\mathrm{MnO}$ & 1.28 & 1.27 & & 0.06 & 0.01 & & 0.00 & 0.00 & & 0.05 & 0.01 & 0.36 & 0.51 \\
\hline $\mathrm{MgO}$ & 3.12 & 3.08 & & 0.02 & 0.00 & & 0.00 & 0.00 & & 7.15 & 7.95 & 0.19 & 0.10 \\
\hline $\mathrm{CaO}$ & 1.10 & 1.01 & & 2.84 & 0.64 & & 0.04 & 0.03 & & 0.03 & 0.05 & 0.02 & 0.07 \\
\hline $\mathrm{Na}_{2} \mathrm{O}$ & 0.00 & 0.00 & & 9.82 & 11.22 & & 1.28 & 1.14 & & 0.10 & 0.13 & 0.00 & 0.01 \\
\hline $\mathrm{K}_{2} \mathrm{O}$ & 0.00 & 0.00 & & 0.22 & 0.12 & & 14.89 & 14.87 & & 9.65 & 9.62 & 0.00 & 0.00 \\
\hline Total & 99.58 & 99.67 & & 100.79 & 100.98 & & 100.37 & 100.58 & & 96.50 & 96.54 & 99.07 & 98.97 \\
\hline Sample & Garn & net & & Plagio & clase & & K-feld & dspar & & Biot & tite & Illme & enite \\
\hline A2 & core & rim & & core & rim & & core & rim & & core & core & core & core \\
\hline $\mathrm{Si}$ & 2.996 & 2.996 & & 2.870 & 2.981 & & 2.994 & 3.001 & & 2.685 & 2.724 & 0.000 & 0.000 \\
\hline $\mathrm{Ti}$ & 0.008 & 0.002 & & 0.000 & 0.001 & & 0.000 & 0.000 & & 0.215 & 0.187 & 1.020 & 1.015 \\
\hline $\mathrm{Al}$ & 2.037 & 2.039 & & 1.124 & 1.019 & & 1.013 & 1.008 & & 1.672 & 1.663 & 0.000 & 0.000 \\
\hline $\mathrm{Cr}$ & 0.009 & 0.011 & & 0.000 & 0.000 & & 0.000 & 0.000 & & 0.017 & 0.007 & 0.002 & 0.000 \\
\hline $\mathrm{Fe}^{2+}$ & 2.366 & 2.386 & & 0.000 & 0.000 & & 0.000 & 0.000 & & 1.374 & 1.301 & 0.942 & 0.952 \\
\hline $\mathrm{Mn}$ & 0.087 & 0.087 & & 0.002 & 0.000 & & 0.000 & 0.000 & & 0.003 & 0.000 & 0.008 & 0.011 \\
\hline $\mathrm{Mg}$ & 0.375 & 0.369 & & 0.001 & 0.000 & & 0.000 & 0.000 & & 0.812 & 0.894 & 0.007 & 0.004 \\
\hline $\mathrm{Ca}$ & 0.095 & 0.087 & & 0.133 & 0.029 & & 0.002 & 0.002 & & 0.002 & 0.004 & 0.001 & 0.002 \\
\hline $\mathrm{Na}$ & 0.000 & 0.000 & & 0.831 & 0.941 & & 0.114 & 0.101 & & 0.015 & 0.019 & 0.000 & 0.001 \\
\hline K & 0.000 & 0.000 & & 0.012 & 0.007 & & 0.870 & 0.866 & & 0.937 & 0.927 & 0.000 & 0.000 \\
\hline Total & 7.999 & 8.000 & & 4.980 & 4.980 & & 4.990 & 4.980 & & 7.732 & 7.726 & 1.980 & 1.985 \\
\hline$X_{P y}$ & 0.128 & 0.126 & $X_{\text {An }}$ & 0.136 & 0.030 & $X_{\text {An }}$ & 0.002 & 0.002 & $X_{\text {Phl }}$ & 0.371 & 0.407 & & \\
\hline$X_{\text {Gross }}$ & 0.033 & 0.030 & $X_{A b}$ & 0.851 & 0.963 & $X_{A b}$ & 0.116 & 0.104 & $X_{\text {Ann }}$ & 0.629 & 0.593 & & \\
\hline$X_{\text {Alm }}$ & 0.809 & 0.815 & Xort & 0.012 & 0.007 & Xort & 0.882 & 0.894 & & & & & \\
\hline$X_{\text {spss }}$ & 0.030 & 0.030 & & & & & & & & & & & \\
\hline
\end{tabular}


Table 3 - Representative samples of the most important analysed minerals for calc-silicate rock 17A.

\begin{tabular}{|c|c|c|c|c|c|c|c|c|c|c|}
\hline \multirow{2}{*}{$\begin{array}{c}\text { Sample } \\
17 A\end{array}$} & \multicolumn{2}{|c|}{ Garnet } & & \multicolumn{2}{|c|}{ Plagioclase } & & \multicolumn{2}{|c|}{ Pyroxene } & \multicolumn{2}{|c|}{ Ilmenite } \\
\hline & core & rim & & core & rim & & core & rim & core & core \\
\hline $\mathrm{SiO}_{2}$ & 38.12 & 38.47 & & 46.17 & 44.97 & & 52.39 & 52.18 & 0.03 & 0.03 \\
\hline $\mathrm{TiO}_{2}$ & 0.07 & 0.04 & & 0.00 & 0.00 & & 0.01 & 0.02 & 54.68 & 54.53 \\
\hline $\mathrm{Al}_{2} \mathrm{O}_{3}$ & 22.01 & 21.69 & & 34.73 & 35.27 & & 0.97 & 1.12 & 0.01 & 0.01 \\
\hline $\mathrm{Cr}_{2} \mathrm{O}_{3}$ & 0.07 & 0.09 & & 0.00 & 0.00 & & 0.06 & 0.14 & 0.02 & 0.00 \\
\hline $\mathrm{FeO}$ & 15.86 & 17.18 & & 0.03 & 0.01 & & 12.72 & 11.90 & 40.11 & 39.87 \\
\hline $\mathrm{MnO}$ & 3.41 & 3.41 & & 0.03 & 0.00 & & 0.59 & 0.44 & 3.62 & 3.66 \\
\hline MgO & 0.90 & 1.07 & & 0.00 & 0.00 & & 9.58 & 10.16 & 0.02 & 0.09 \\
\hline $\mathrm{CaO}$ & 19.18 & 17.96 & & 18.41 & 19.25 & & 23.34 & 23.56 & 0.03 & 0.15 \\
\hline $\mathrm{Na}_{2} \mathrm{O}$ & 0.00 & 0.00 & & 0.60 & 0.26 & & 0.09 & 0.13 & 0.00 & 0.01 \\
\hline $\mathrm{K}_{2} \mathrm{O}$ & 0.00 & 0.00 & & 0.02 & 0.00 & & 0.00 & 0.01 & 0.01 & 0.01 \\
\hline Total & 99.62 & 99.91 & & 100.05 & 99.77 & & 99.88 & 99.90 & 98.52 & 98.35 \\
\hline Sample & Gar & net & & Plagio & clase & & Pyro & xene & Ilme & enite \\
\hline $17 A$ & core & rim & & core & rim & & core & rim & core & core \\
\hline Si & 2.982 & 3.006 & & 2.121 & 2.077 & & 1.999 & 1.990 & 0.001 & 0.001 \\
\hline $\mathrm{Ti}$ & 0.004 & 0.002 & & 0.000 & 0.000 & & 0.000 & 0.000 & 1.037 & 1.035 \\
\hline $\mathrm{Al}$ & 2.030 & 1.998 & & 1.881 & 1.921 & & 0.044 & 0.050 & 0.000 & 0.000 \\
\hline $\mathrm{Cr}$ & 0.004 & 0.006 & & 0.000 & 0.000 & & 0.002 & 0.004 & 0.000 & 0.000 \\
\hline $\mathrm{Fe}^{3+}$ & 0.000 & 0.000 & & 0.001 & 0.000 & & 0.000 & 0.000 & 0.000 & 0.000 \\
\hline $\mathrm{Fe}^{2+}$ & 1.037 & 1.123 & & 0.000 & 0.000 & & 0.406 & 0.380 & 0.846 & 0.842 \\
\hline $\mathrm{Mn}$ & 0.226 & 0.226 & & 0.001 & 0.000 & & 0.019 & 0.014 & 0.077 & 0.078 \\
\hline $\mathrm{Mg}$ & 0.105 & 0.125 & & 0.000 & 0.000 & & 0.545 & 0.577 & 0.001 & 0.003 \\
\hline $\mathrm{Ca}$ & 1.608 & 1.504 & & 0.906 & 0.953 & & 0.955 & 0.962 & 0.001 & 0.004 \\
\hline $\mathrm{Na}$ & 0.000 & 0.000 & & 0.053 & 0.023 & & 0.006 & 0.010 & 0.000 & 0.000 \\
\hline $\mathrm{K}$ & 0.000 & 0.000 & & 0.001 & 0.000 & & 0.000 & 0.000 & 0.000 & 0.000 \\
\hline Total & 7.996 & 7.990 & & 4.965 & 4.974 & & 3.976 & 3.987 & 1.963 & 1.964 \\
\hline$X_{P y}$ & 0.035 & 0.042 & $X_{\text {An }}$ & 0.944 & 0.976 & $X_{\text {Ens }}$ & 0.286 & 0.301 & & \\
\hline$X_{\text {Gross }}$ & 0.540 & 0.505 & $X_{A b}$ & 0.055 & 0.024 & $X_{\text {Fsl }}$ & 0.213 & 0.198 & & \\
\hline$X_{\text {Alm }}$ & 0.348 & 0.377 & Xort & 0.001 & 0.000 & Xwo & 0.501 & 0.501 & & \\
\hline$X_{\text {spss }}$ & 0.076 & 0.076 & & & & & & & & \\
\hline
\end{tabular}


Table 4 - Summary of the geothermobarometric results obtained for the studied samples.

\begin{tabular}{|c|c|cc|cc|cc|}
\hline \multirow{2}{*}{ Rock type } & Sample & \multicolumn{2}{|c|}{ Metamorphic Peak } & Calculated & $\begin{array}{c}\text { Geothermal } \\
\text { Depth (km) }\end{array}$ & \multicolumn{2}{|c|}{$\begin{array}{c}\text { Retrogressive } \\
\text { Stage }\end{array}$} \\
& & G & T & & & & T (oc/km) \\
Staurolite Schist & P11a & 5.7 & 635 & 21.1 & 30.1 & 4.9 & 437 \\
& A2-1 & 7.9 & 780 & 29.2 & 26.7 & 6.2 & 560 \\
Metatexite & A2-2 & 7.7 & 769 & 28.5 & 27.0 & 5.9 & 545 \\
Calc-silicate & 17A-1 & 7.6 & 796 & 28.1 & 28.3 & 5.4 & 512 \\
(within metatexites) & 17A-2 & 7.6 & 812 & 28.1 & 28.9 & 3.5 & 421 \\
\hline
\end{tabular}

Pressure is in kbar. Temperature is in ${ }^{\circ} \mathrm{C}$. 


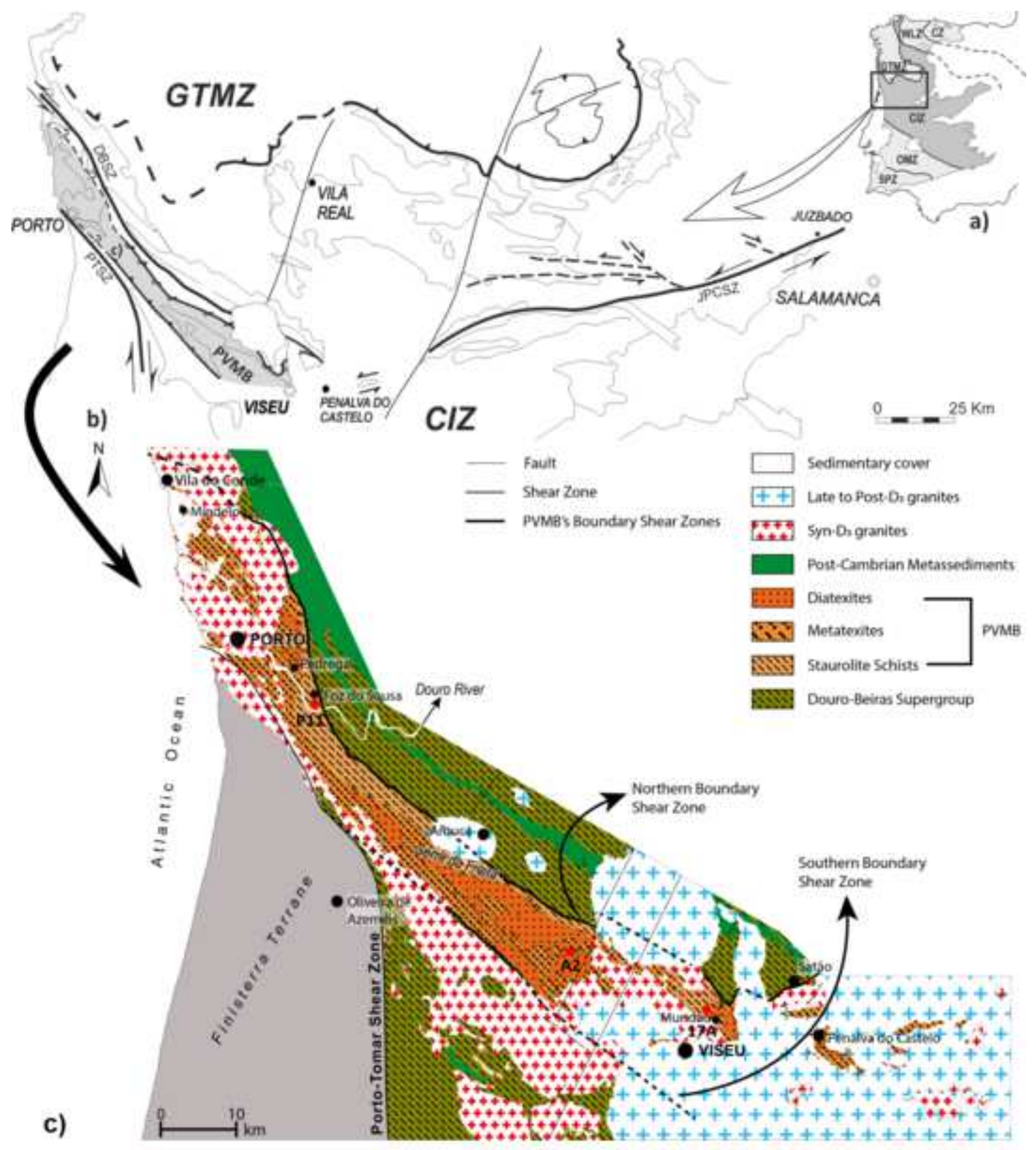




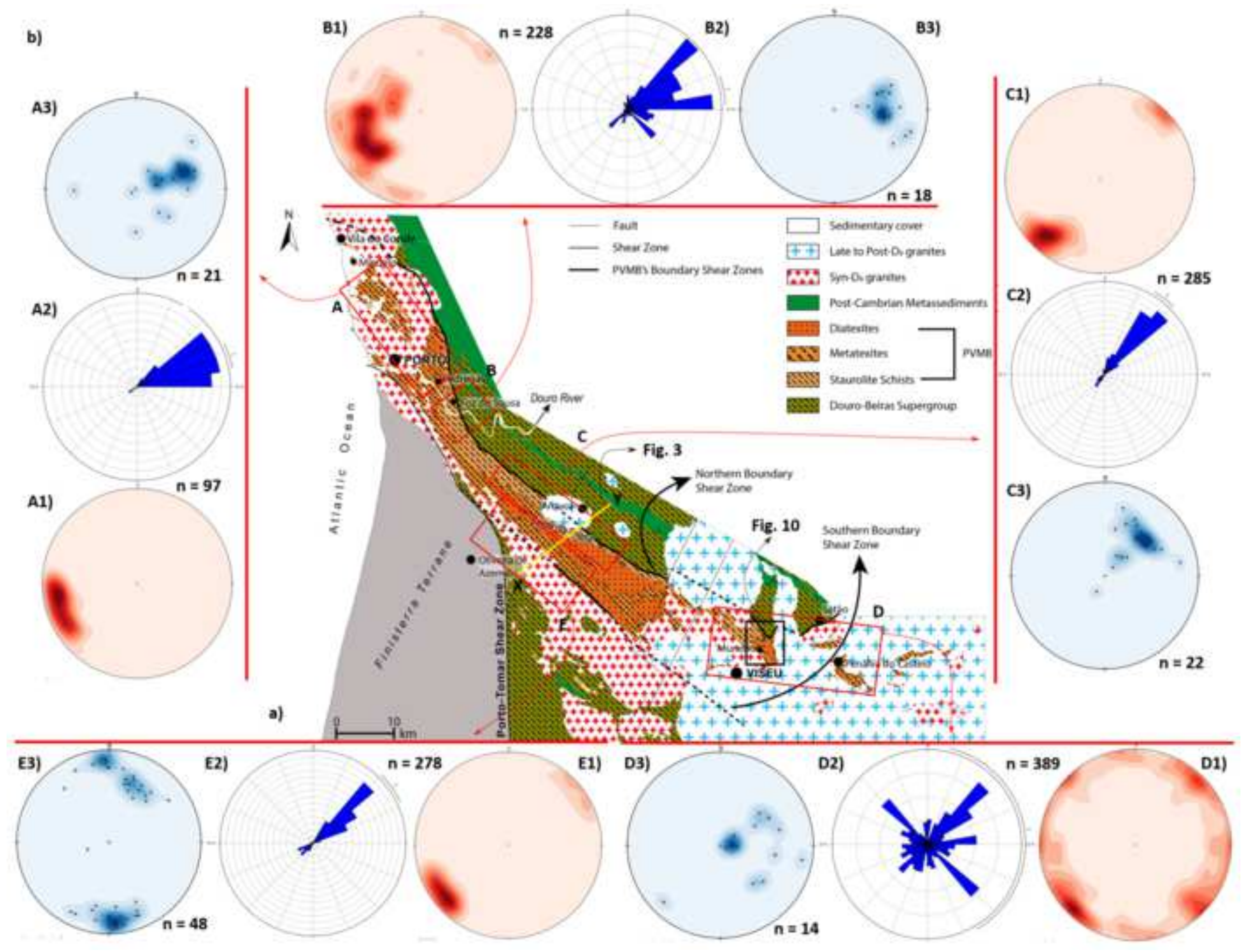




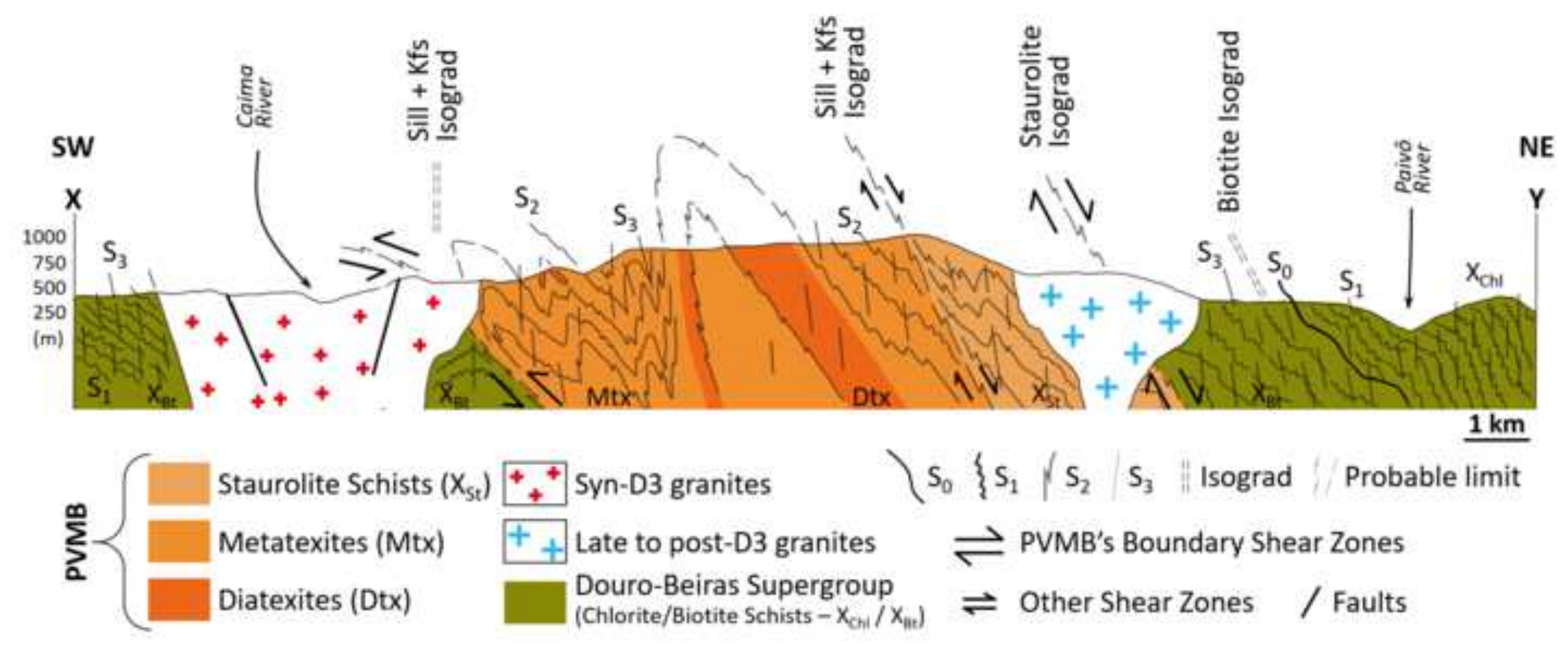




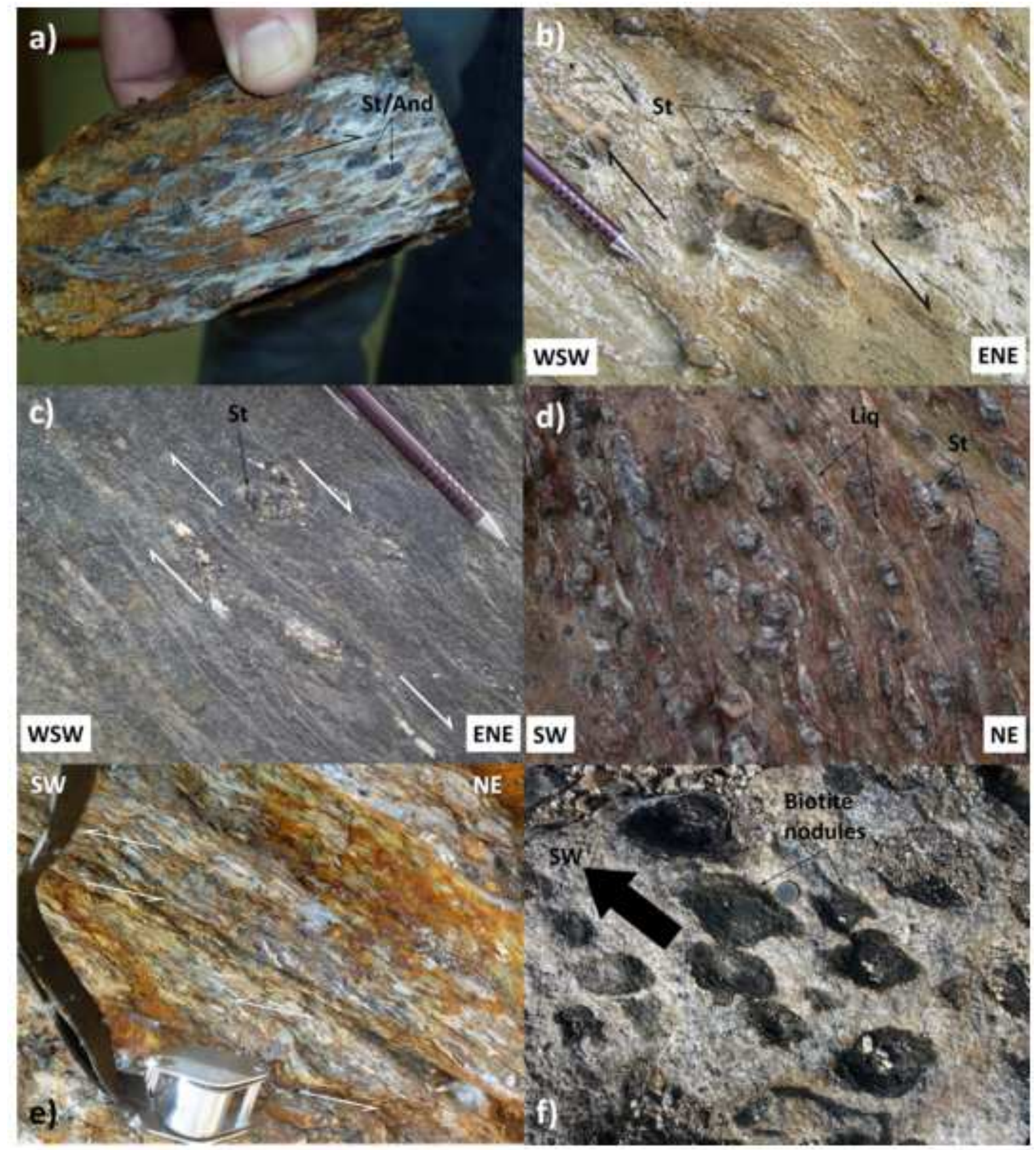

\section{\begin{tabular}{|l|l|}
\hline ENE & SW \\
\hline
\end{tabular}}




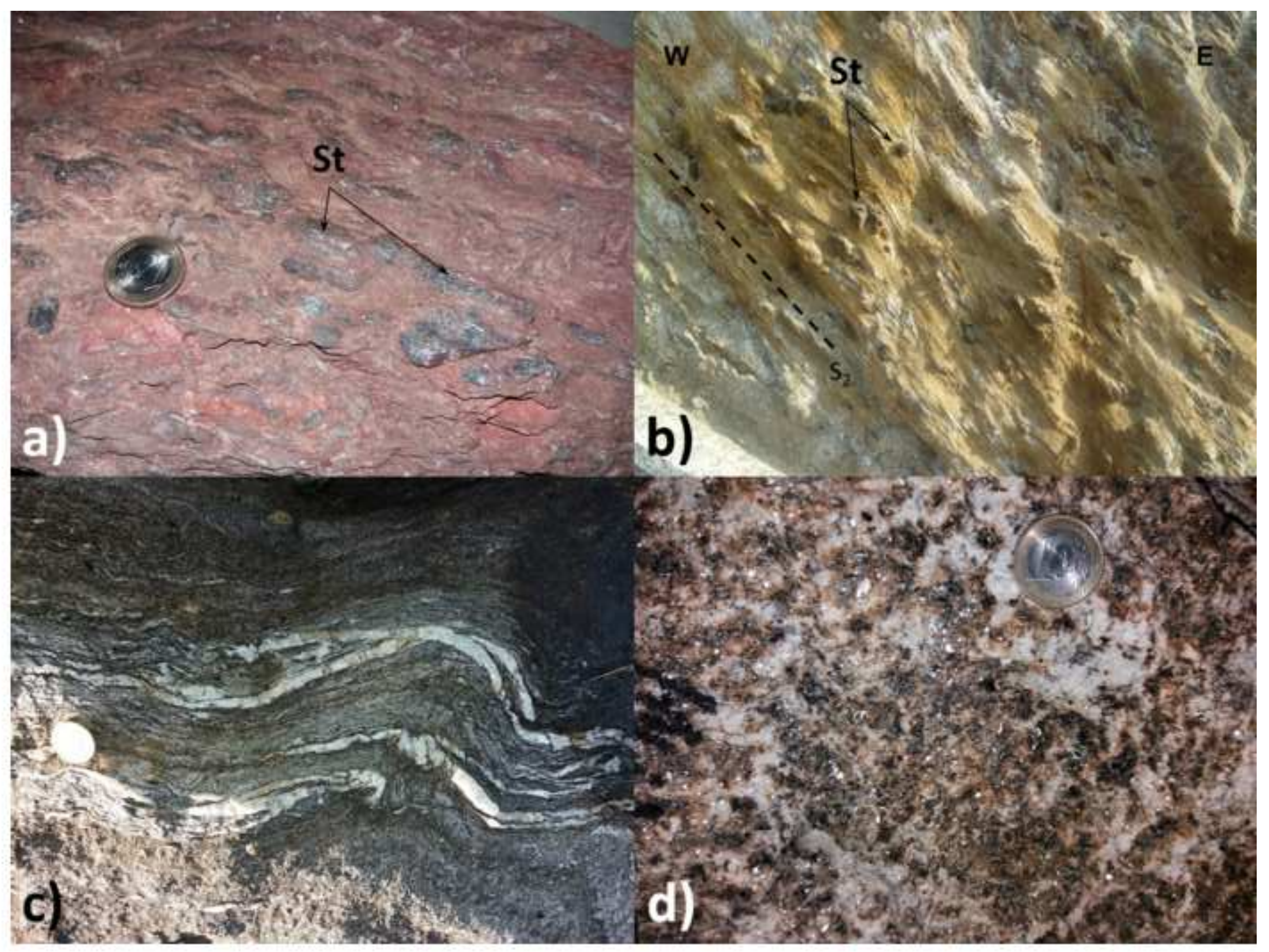




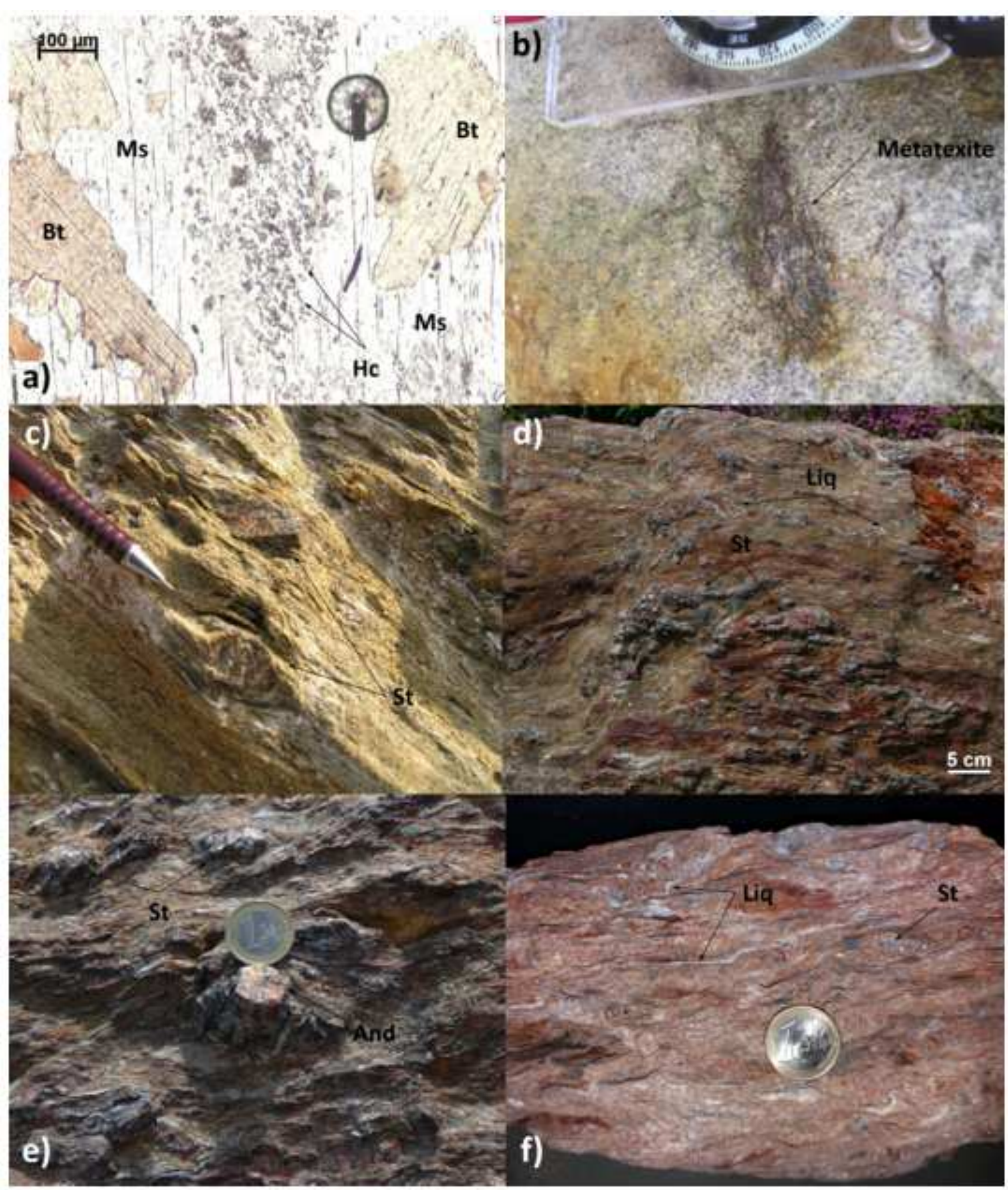

f) 

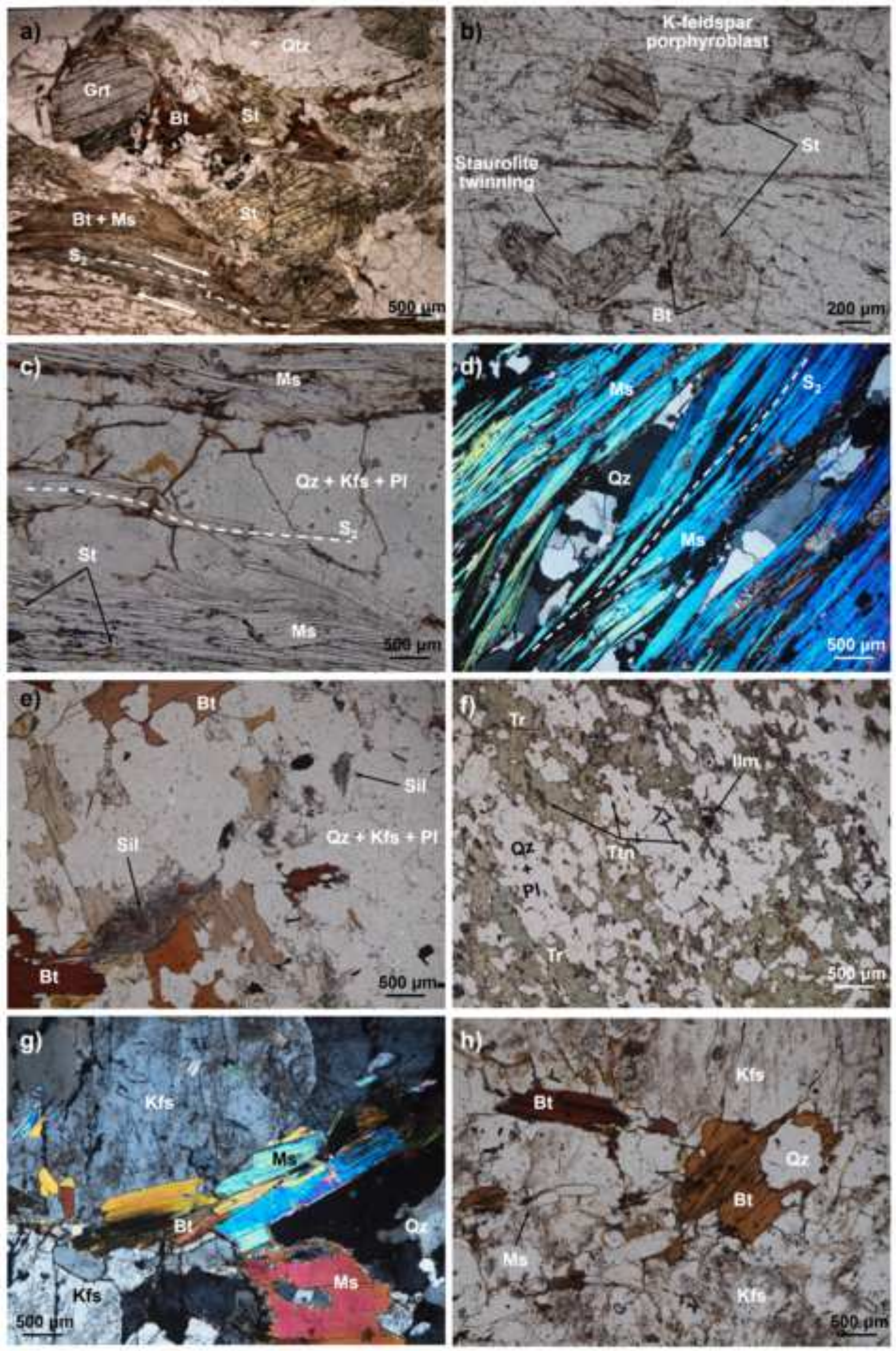


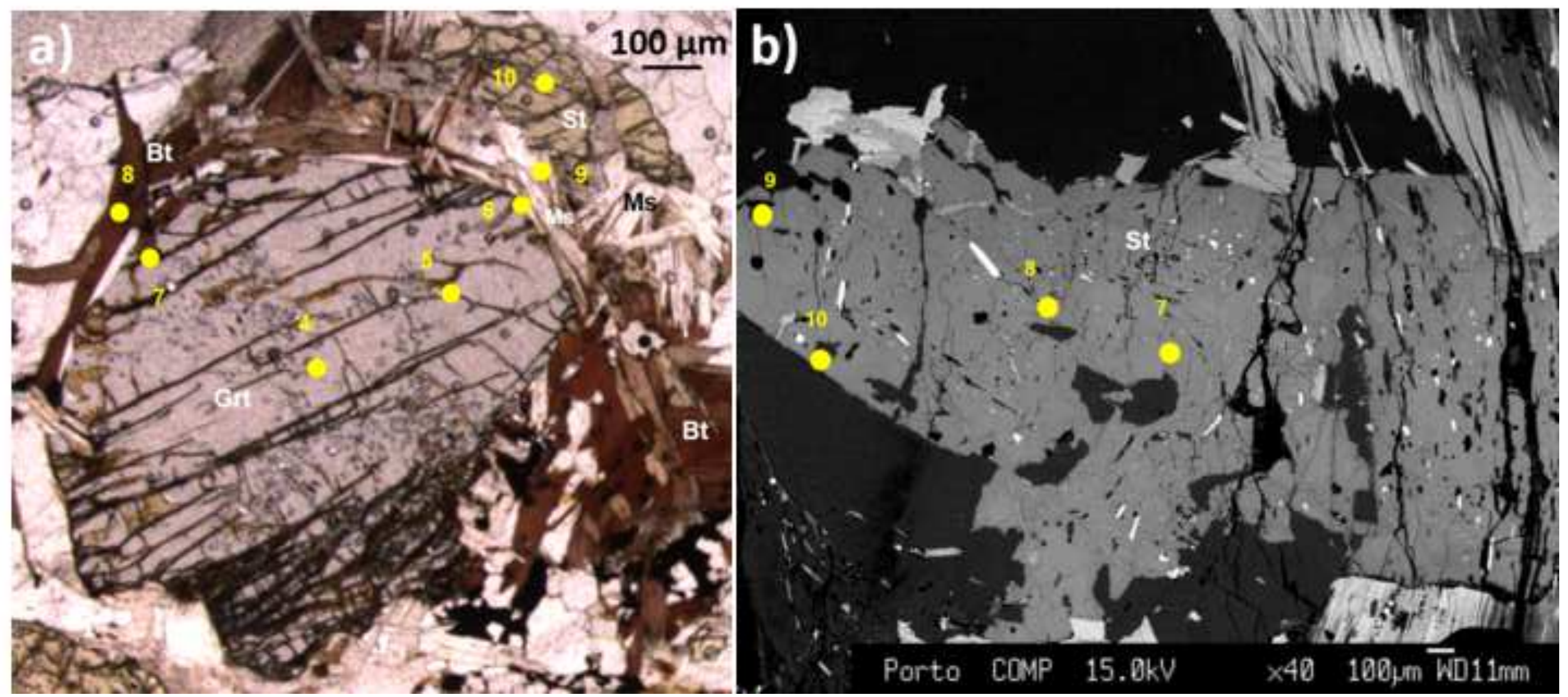




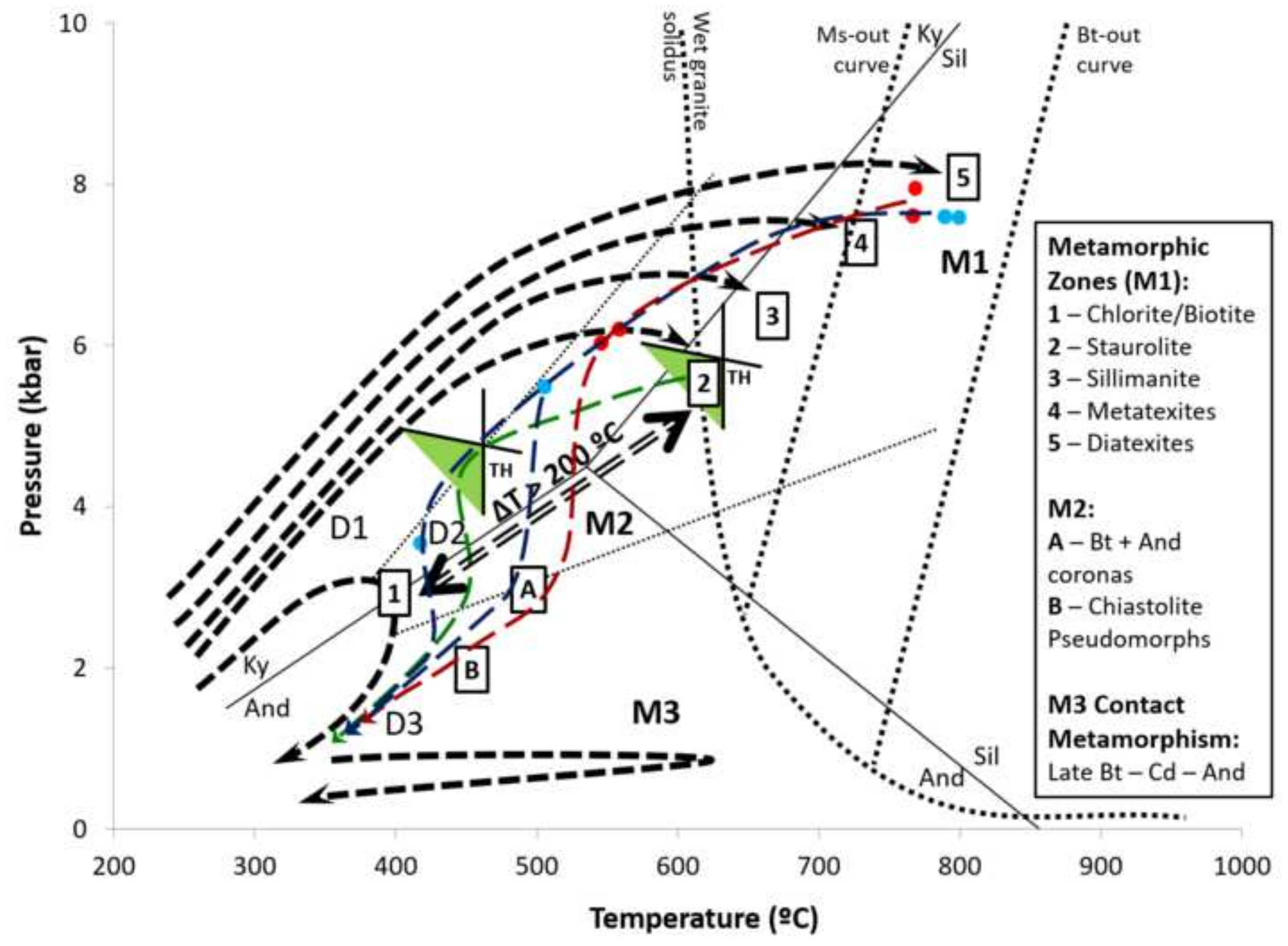




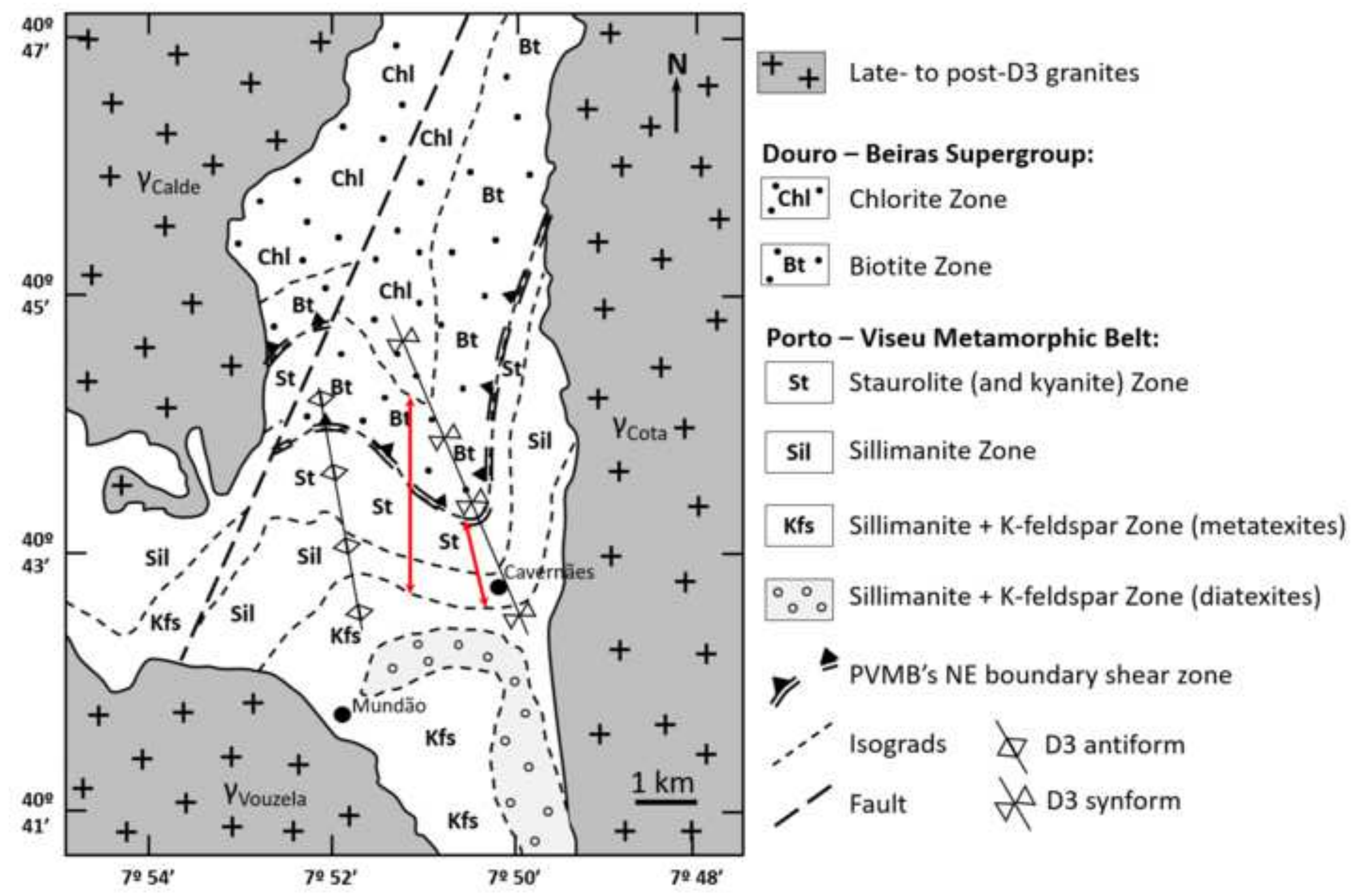




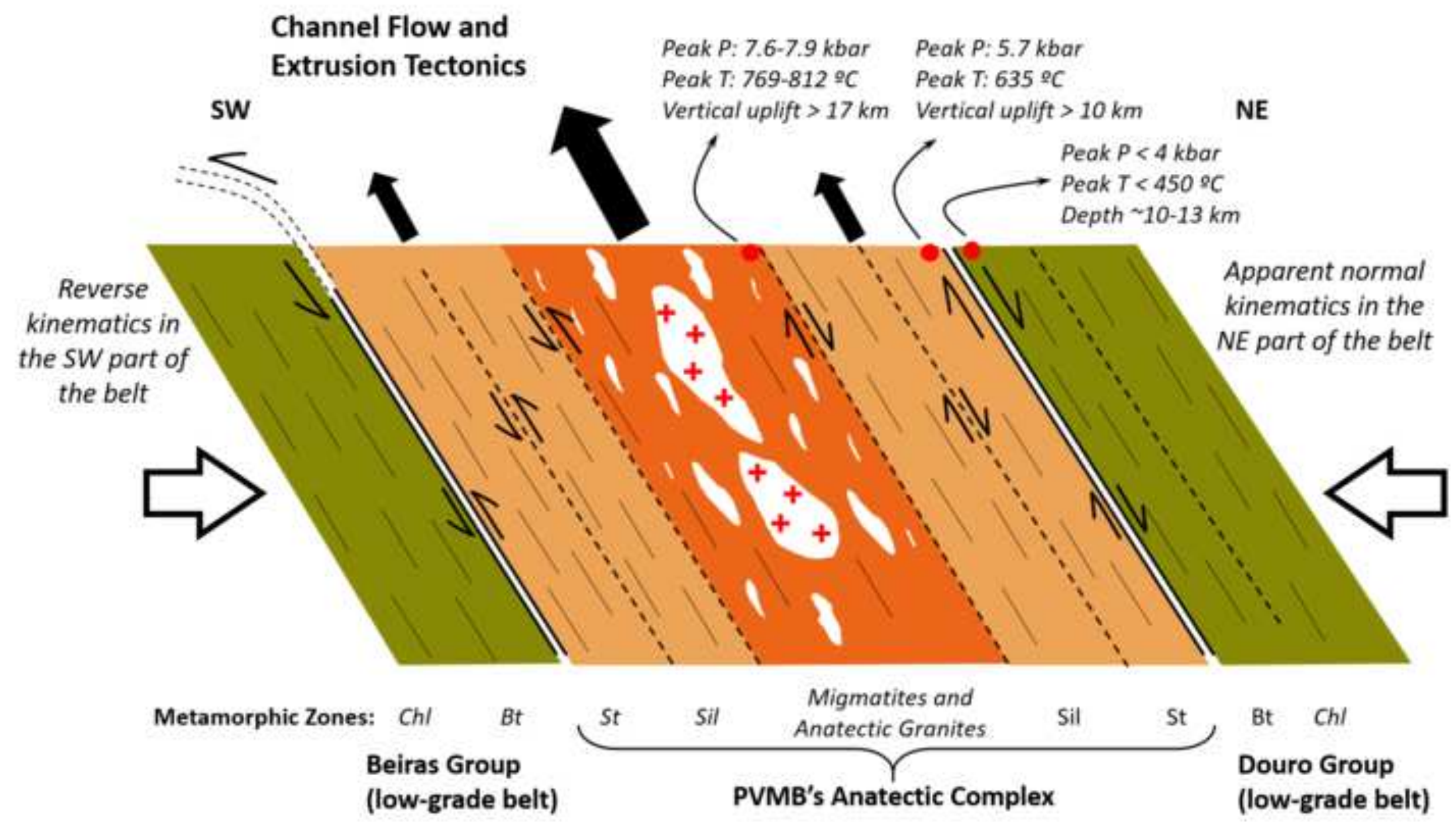




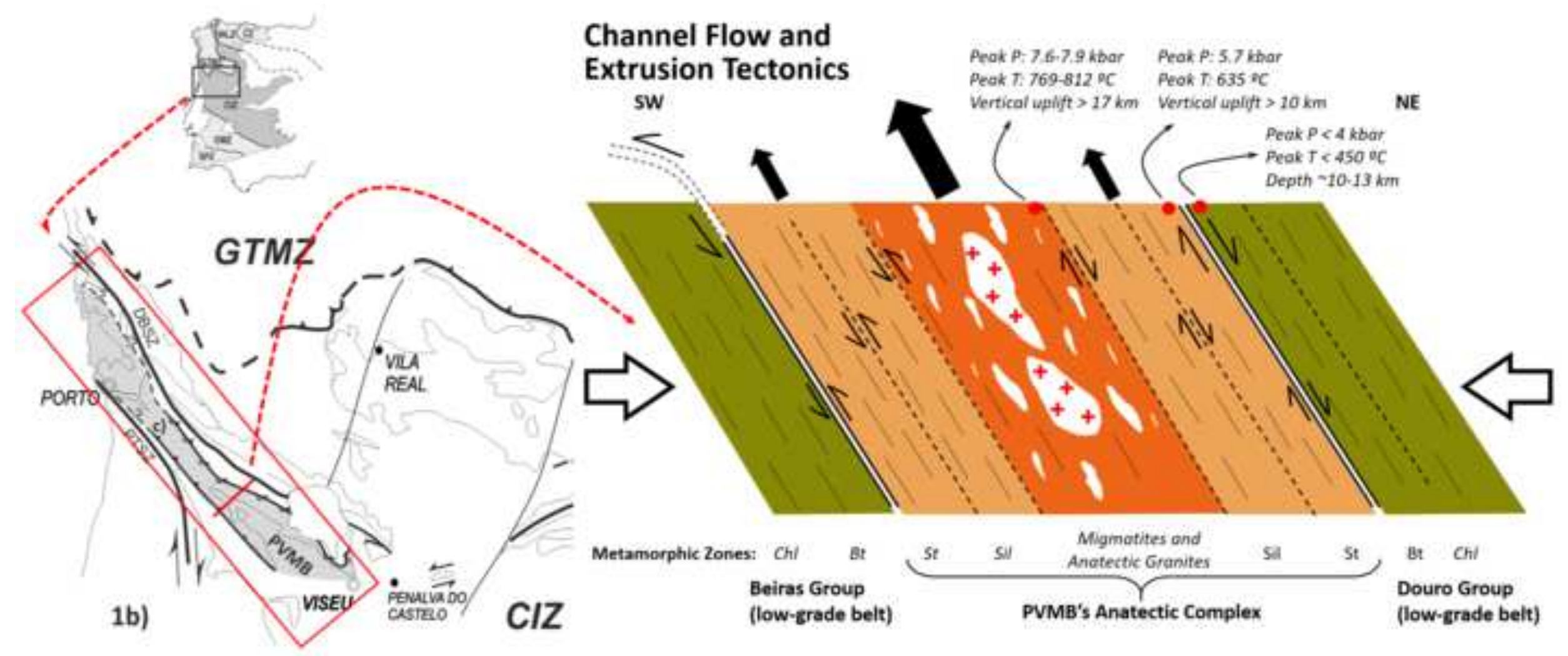

\section{Channel Flow and} xtrusion Tectonics

T: 769-812 oC

$10 \mathrm{kn}$

Peak T $<450$ oC epth $-10.13 \mathrm{~km}$

Beiras Group

PVMB's Anatectic Complex

Douro Group

(low-grade belt)

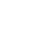

